\title{
Oluşumsal Yapısalcılığın İlkeleri ve Zola'nın Emek Adlı Romanı Üzerinde Çözümleme ${ }^{1}$
}

\author{
Serhat TERTEMIZ² ve İrfan ATALAY ${ }^{3}$
}

$\ddot{O} z$

Toplumsal çatışmaların veya toplum yaşamının düzenli işlemesine engel olan durumları içeren romanlar, toplumcu gerçekçilik anlayışını benimseyen Marksçı öğreti ve bu öğretiden çıkmış eleştiri yöntemleri için oldukça uygun birer inceleme alanıdır. Toplumbilimsel eleștiri yöntemlerinden birini olușturan Lucien Goldmann'ın olușumsal yapısalcılık yöntemi de anamalcı dizgenin neden olduğu sorunları ve mutsuzlukları ve bunlara karşı önerilen çözüm yollarını anlatan romanların çözümlenmesi veya eleştirisinde verimli sonuçlar ortaya koyar. Romanın içyapılarının yanı sıra oluşum sürecini etkileyen ve tetikleyen metin dışı yapıları da araștırmayı öneren yöntem, toplumun aydın temsilcisi konumundaki yazarın, sorunlar karşısında oluşturduğu dünya görüşünün sorgulamasını yapar. Yöntemin uygulanması aşamasında farklı yapıların derinlemesine araștırılması tutarlı açıklamaları doğurur. Ütopik sosyalizmin savunulmasının yapıldığı Zola'nın Emek adlı yapıtı, işçi emeğinin özgürleşmesine bağlı olarak yaşamdaki tüm duygu ve hazların anlam kazanacağı ve insanlığın bu sayede mutluluğa ereceği tezi üzerine kuruludur. Sanayiye koşut olarak gelişen burjuva sınıfının XIX. yüzyılda yaptığ1 emek sömürüsünün insanları köleleştirdiğine yer veren yapıt, emek köleliğinden kurtulmak için yeni bir dizge önerir. Yapit, işçi sınıfının her geçen gün biraz daha yoksullaşmasına neden olan ağır koşulların mantıklı ve akılcı çözümlerle üstesinden gelinebileceğini gösterirken, Zola'nın ütopik sosyalist Fourrier, Saint-Simon ve daha birçok toplumcu sosyalist düşünür ve yazarlardan esinlenerek oluşturduğu düşüncelerini doğalcı yöntemlerle sunar.

\section{Anabtar Kelimeler: Oluşumsal yapısalcılık, Dünya görüşü, Olası bilinç, Sorunsal kahraman, Emek.}

\section{The Principles of Constructivist Structuralism and Analysis of the Novel by Zola Emek}

\begin{abstract}
Novels, narrating events of social conflicts or the events preventing regular functioning of public life are a very suitable field of study for Marxist doctrine which adopts the understanding of social realism and the methods of criticism that have passed from this doctrine. Lucien Goldmann's method of constructive structuralism which is one of the methods of sociological criticism gives fruitful results in analyzing or criticizing novels that describe the problems and misfortunes caused by the dominant system and the proposed solutions against them. The method, which suggests exploring the nontextual structures that influence and initiate the formation of process as well as the internal structures of the novel dispute worldview of the writer, who is the intellectual representative of society, in front of the problems. Detailed study of various structures using the method leads to consistent explanations. Zola's work, where Utopian socialism is defended is based on the thesis that all emotions and pleasures in life will make sense, and humanity will achieve happiness through the liberation of labor. Bourgeoisie developed in parallel to industries. The work, which is inferior to the exploitation of labor offers a new system of getting rid of labor slavery. While the work shows the harsh conditions making working class become poorer every day can be overcome with logical and rational decisions, Zola presents his ideas inspired by the utopian socialist Fourier, Saint-Simon and many other socialist thinker and writers, naturalistic methods.
\end{abstract}

Key Words: Genetic structuralism, Worldview, Possible consciousness, Problematical hero, Emek (Travail)

\author{
Atıf İçin / Please Cite As: \\ Tertemiz, S. ve Atalay, İ. (2020). Oluşumsal yapısalcıllğın ilkeleri ve Zola’nın Emek adlı romanı üzerinde çözümleme. \\ Manas Sosyal Arasturmalar Dergisi, 9(2), 665-683.
}

Geliş Tarihi / Received Date: 26.04.2019

Kabul Tarihi / Accepted Date: 12.06.2019

\footnotetext{
${ }^{1}$ Bu makale Serhat Tertemiz'in Une étude sur Travail d'Émile Zola dans le cadre de la méthode de structuralisme génétique adlı yüksek lisans tezi ve İrfan Atalay'ın Jean-Paul Sartre'm Özgürlük Yolları adl yapıtına oluşumsal yapısalc bir yaklaşım adlı doktora tezindeki kuramsal bölüm temel alınarak üretilmiştir.

2 Tekirdağ Namık Kemal Üniversitesi Fransız Dili ve Edebiyatı Anabilim Dalı, Yüksek Lisans Programı mezunu. serhattertemiz@gmail.com ORCID:0000-0002-6553-1000

3 Doç. Dr. - Tekirdă̆ Namık Kemal Üniversitesi Fen-Edebiyat Fakültesi Fransız Dili ve Edebiyatı Bölümü. iatalay@nku.edu.tr ORCID: 0000-0002-4437-5539
} 


\section{Giriş}

"Emek" kavramı insanlık tarihi boyunca bireyin toplumdaki rolünü ve işlevini belirleyen en önemli öğe olmuştur. İnsanın üretim ve tüketim ilişkileri içerisinde oynadığı rol onun mevcut dizge içerisindeki durumunu ve konumunu anlamamızdaki en başat unsurlardan bir tanesidir. Emek, XIX. yüzyllın en çok tartışıla gelen ve dönemin bütün ideolojilerini ve sınıfsal yapılarını belirleyen en önemli kavramdır. Émile Zola'nın Emek adlı romanı bu dönemin son çeyreğinde kaleme alınmıs olup döneminin toplumsal yapılarını, ideolojilerini ve sınıf çatışmalarını en iyi yansıtan yapıtlarından biridir. Germinal adlı romanının tersine, yazar bu romanında toplumsal uzlaşmayı sağlayacak bir tutum takınır. Yazar, toplumu fizyolojik ve ideolojik bakımdan inceleyerek, toplumun bütün yapılarına ve kurumlarına doğalcı yöntemlerle ayna tutup insanların en derin özlemlerini keşfetmeye çalışış ve kurgusal bir anlatı ve uzamda bu özlemleri okurlarının zihinlerinde canlandırmaya çalışmıştır. Kurgusal olarak gerçeklikten ütopyacıllı̆̆a doğru ilerleyen romanın anlatısı, okuru yeni bir dünyanın oluşturulabileceğine ikna etmeye çalışarak yenidünya düzeniyle ilgili bilgi verir ve bu dizgenin savunuculuğunu yapar. Yapıtın kurgusunda ve uzamında oluşturulan bu yeni dizge, dönemin birçok ütopyacı toplumcu, anarşist ve olgucu düşünürlerinden etkilenerek oluşturulmuştur. Yazar döneminin önemli düşünsel akımlarından dersler çıkararak bunlar arasında bir uzlaşı ve sentez oluşturmak niyetindedir. Kuramsal olarak toplumcu gerçekçi yazının taslağ1 yapılmamış ve çerçevesi çizilmemiş olmasına rağmen yazarın bu yapıtı bu yazınsal kuramın bütün özelliklerini taşır. Yapıt okunduğunda, yazarın bu yapıtı kâğıda dökerken en başat kaygısının ütopik sosyalizm diye adlandırılan bir öğretiyi insanlara tanıtmak ve onun üstünlüğünü kabul ettirmek olduğu açıkça anlaşılır. Gelecekte nasıl bir dünya oluşacağını tasavvur ederken bunu toplumcu, anarşist ve olgucu öğretilerin ilkelerini temel alarak gerçekleştirir ve anamalcı dizgeye çok ciddi eleştiriler getirir. Yazara göre insanlığın bu dönem boyunca yaşadığı bütün sorunların kaynağı sermaye ve mülkiyete dayalı iktisadi ve siyasi dizgedir. Yazar ömrünün sonlarına doğru toplumcu ve anarşist çevrelerle sıkı ilişkiler kurup bu öğretilerin başyapıtlanı üzerinde detaylı incelemeler yapmıştır. Saint-Simon ve Charles Fourier'in insani tutkuların özgürleşmesi, sermaye ve mülkiyetin değil emeğin yüceltilmesi, herkesten gücü yettiği kadar alınması ve herkese ihtiyacı olduğu kadar verilmesi düşüncelerinin bu yapıtta taraftarlı̆̆ını yapmıştır. Ayrıca Darwin'in savaş ve rekabeti savunan kuramı yerine Kropotkin'in yardımlaşma ve dayanışmaya dayalı düşüncelerini savunmuştur.

Marksçı düşünceden yola çıkarak oluşturulan Lucien Goldmann'ın oluşumsal yapısalčllk yöntemi bu tarz yapitları en bütüncül ve en tutarlı şekilde okuyup yorumlayabileceğimiz yöntemlerden biridir. 50’li yıllarda ortaya çıkan ve kuramcının ölümüne kadar geliştirmeyi sürdürdügü bu yöntemin en önemli kaynakları Pour une sociologie du roman ve Le Dieu Cachédir. Goldmann'in bu çalş̧maları toplumun oluşturduğu alt ve üstyapıların yazınsal ve düşünsel yapıtlar üzerinde ne derecede etkili olduklarını ortaya koyan kuramsal yapıtlardır. Marksçı kuramcı yazınsal ya da düşünsel bir yapıtın ilk olarak kendi içkin unsurlarının ortaya konulmasıyla anlaşılması gerektiğini savunur. Anlama aşamasında elde edilen veriler ışı̆̆ında yapıt, anlatının geçtiği dönemin toplumsal gerçeklikleriyle açıklanmaya çalışılır. Açıklama aşamasında yapıt, dönemin tarihsel olayları, toplumsal yapıları, sınıf çatışmaları ve toplumun olası bilinci ve ideolojileriyle açılanır. Gerçekleştirilecek bu iki aşamayla birlikte eytişimsel özdekçi yöntem tamamlanmış olur. Yöntemin en başat amaçlarından biri de yapıtın içkin ve aşkın unsurlarından yola çıkarak yapıt ve yazar tarafından ortaya konan dünya görüşü veya ideolojinin tespit edilmesi ve somut verilerle açıklanmasıdır. Bu çalışmamızda Hegel'in sanat, Weber'in yanlış bilinç (fausse conscience), Lukács'in tip ve olası bilinç, Roland Barthes'ın yapısalcılık, Émile Durkheim'ın sosyoloji ve Piaget'nin psikoloji üzerine yaptıkları çalışmalardan etkilenerek oluşturulan bu yöntem çerçevesinde Zola'nın Emek adlı yapitı üzerinde bir çözümleme çalışmasına yer verilmiştir. Yapıt üzerinde daha önce yazın toplumbilimsel bir çalışma yapılmamıs olması ve eytişimsel bir yöntemle yapıta bütüncül ve tutarlı bir tavırla incelemeye almamız çalışmanın önemini oluşturmaktadır.

\section{Oluşumsal Yapısalcılık Nedir?}

XIX. yüzyılda olguculuk, bilgi kuramı, budunbilim ve görüngübilim alanlarındaki gelişmeler sayesinde tarih ve toplumbilim alanındaki çalışmaların bilimsellik değeri artmıştır. Yazın toplumbilimi alanında yapılan çalışmalar ve ortaya çıkartılan kuramlar somut verilere ve deneye dayanarak inceleme yapılmasını önerir. Ancak Émile Durkheim'ın Toplumbilimsel Yöntemin Kurallar, Georges Lukács'in Tarih ve Sinnf Bilinci ve Max Weber'in Bilim Kuramı Üzerine Incelemeler adlı yapitlarından sonra toplumbilimsel incelemeler daha nesnel hale gelmiş ve gerçekçi sonuçlar alınmaya başlanmıştır. Bu araştırmacıların sözü edilen çalısmalarına kadar öznel nitelikli olan çalışmalar, Durkheim'la birlikte toplumbilimsel nesnelleşme çabasına girmişse de, çalsşmaları nesnellikten uzaklaştıran ideoloji sorunu her zaman sorun olarak kendisini göstermiştir. Toplumbilimsel çalışmalar bu sorunu Marx'nn bilinç ve Hegel'in eytişim ile ilgili çalışmalarını yeniden 
yorumlayan Lukács sayesinde aşmıştır. Markş̧̧ı yazın kuramcıları toplumsal ve tarihsel gerçekliklerle, kurgusal bir yazınsal yapıt arasında çok ciddi benzeşim ve bağlaşım olduğunu savunurlar. Yazınsal yapıt toplumsal yapıları ve bilinç türlerini belirli ya da birçok bakış açısından yansıtan anlatılardır. Bir üstyapı unsuru olan sanat, toplumu oluşturan altyapılardan etkilenir ve ortaya çıkan yazınsal veya sanatsal yapıtta de bunun etkileri görülür. Bu bağlamda, yapıtta insana özgü bütün yapılar anlamlıdır. Bu anlamlı yapılar bir oluşumun sonucudur. Yazınsal yapıtı oluşturan aydın sıfatlı duyarlı özne, bir toplumsal sınıfa mensuptur. Bir toplumsal sınıfa ait olan her birey de o sınıfin olası bilincine sahiptir. Kuşkusuz toplumunun bilincine sahip duyarlı özne konumundaki yazar, mensubu olduğu sınıfın değerlerini taşıyabileceği gibi bunlara karşı da olabilir. Yazar, yaratmış olduğu imgesel evrende yer alan toplumsal değerleri reddeder ve toplumu ileriye götürecek değerleri savunur, toplumun karşılaştığı sıkıntı ve engellere çare ve çözüm arayışında bulunur, toplum bilimcinin etkisi altında kendince bir dünya görüşü şekillendirir. "Goldmann, yapıtı yönlendiren dünya görüşünü anlamlı yapı olarak adlandırır. Yazınsal bir yapıtın anlam ve değeri ona göre bir toplumsal gruba bağlıdır” (Atalay, 2007, s. 26). Bunu gerçekleştiren her sanatçı ilerici bir dünya görüşüne sahiptir. Olası bilinç diye de adlandırılan toplum bilinci kişiye göre bazı farklılıklar ve tutarsızlıklar gösterse de, yazarın en başat amacı ortak bilinci (fr. conscience collective) ortaya koymaktır ve bir yazınsal yapıt bu bilinci ne kadar başarılı bir şekilde ortaya koyabilirse yapıt o derecede büyük niteliği kazanıp incelenmeye değer görülür (Munier, 2001, s. 189-190). Buna bağlı olarak, "büyük yazarlar, bir sınıfın olası bilincinin en yüksek derecesine karşıllk olan bir dünya görüşünü az çok tutarlı bir biçimde açıklayan yazarlardır. Bu durum özellikle filozoflar, yazarlar ve sanatçılar için geçerlidir" (Goldmann, 1977, s. 56).

Goldmann, Kant üzerine yaptığı doktora tezi, Jean Piaget ile olan teması, Marx'ın bilgi kuramı ve tarihsel eytişim ilkelerini temel alarak yazdığı Diyalektik Araștırmalar adlı çalısmalarında temellendirmeye başladığı ve daha birçok düşünsel kuramdan etkilenerek oluşturduğu eytişimsel inceleme yöntemini Le Dien Caché ve Pour une Sociologie du Roman adlı çalışmalarında uygular ve oldukça başarılı sonuçlar elde eder. Yöntemin hareket noktası, bir toplumsal sınıfa mensup duyarlı ve farkındalığı yüksek bir bireyin toplumun eğilimleri ve ortak bilincini yazınsal ya da sanatsal yapitlar aracilğğyla okura ya da toplum bireylerine aktardığ1 görüşüdür. Goldmann, 1947 yllında yayımlanan "Eytişimsel Özdekçilik ve Yazın Tarihi”" (Matérialisme dialectique et histoire de la littérature) adlı makalesinde dünya görüşünün tanımını yapar. İdeolojileri ilerici ve gerici olarak ikiye ayırır. İşçi sınıfının yeni ülkülerini savunan görüşleri ilerici, eski düzeni savunan ideolojileri gerici diye sınıflandırır. Ona göre ideoloji, "sınıf mensuplarını birleştiren ve diğer sinıflara duyulan özlem, duygu ve düşünceler bütünüdür4” (Goldmann, 1976, s. 26).

Yazın konusunun ana merkezinde yapıt bulunur. Yazarlar aracıllğıyla üretilen her yapıt bir okur tarafindan algilanır. Ancak okurun algisını kolaylaştırıp yönlendirmekte bir yöntem veya kuramın kullanılması hem anlaşılmayı, hem de içeriğin anlaşılır ulamlar halinde verilmesini kolaylaştırır. Toplumsal yaşam alanlarındaki belirli bir gerçekliği anlaşılabilir kıllmak için dizgeli ve bütüncül bir şekilde ortaya konan düşünceler, gözlemler ve izlenimler bütünü olarak tanımlanabilen kuramın ölçütleri çerçevesinde Goldmann'ın çözümleme kuramı bizim çalısmamızı kolaylaştıracaktır:

Lucien Goldmann'n oluşumsal yapisalcalle diye adlandirdiğg toplumbilimsel yöntemi bir yapitt, içinde barndirdiğg anlaml bütünlüklerden bareketle, toplum gerçekliklerini göz önünde bulundurarak çözümlemeyi amaçlar. Goldmann, günümüz toplumlarmm antik dönem toplumlarmm aksine gerçek değerlerini yitirdiklerini ve yitirilen bu değerlerin arayışı için boşuna bir çaba içinde olduklarmı söyler (Atalay, 2016, s. 387).

Oluşumsal yapısalcıllğga göre yazınsal yapıt, bir yansıma değil daha çok bir yanıt niteliğindedir. Yaratıcı özne/yazar, deneyimlerine dayanarak dış dünyadaki yansımalarıyla kendini yapıtına yansıtmaya çalışır. Goldmann, bir tinbilimci olan Jean Piaget'den aldığı bu düşünceyi Marksçı bakış açısıyla geliştirir. Ona göre özne, kısmen de olsa, iye olduğu ortak bir ekonomik altyapıyı oluşturan toplumsal sınıfin bilincindedir. Dolayısıyla bir yapıtın eleştirisini gerçekleştiren eleştirmen, yapıtı oluşturan yapıları ve bu yapıları tutarlı hale getiren aydının iye olduğu toplumsal sınıfın bilinç yapısını araştırması gerekir. Marksçı kuramcilar sosyo-ekonomik yap1 ile toplumsal betimlemeler arasında ciddi bir ilişki olduğunu ve bunun mevcut koşullara göre bir dünya görüşü oluşturduğunda hemfikirdirler. Toplumlar için geride birakılan çağlar ve tarihsel dönemler, toplumsal sınıflar arasındaki ilişkileri ve mücadeleleri, güçlü ve zayıf yönleri nitelendirir. Bundan hareketle, güçlülük ya da zayıflık ilişkileri günlük yaşantımızı oluşturan ekonomi, 
siyaset, toplum vb. öğeler altyapıları; din, ahlak, felsefe, sanat, hukuk, kültür vb. gibi unsurlar da üstyapıları belirler.

Marx’ın özdekçi bir zemine oturttuğu Hegel'in tez, antitez ve sentez olgularından oluşan eytişim kavramı doğrultusunda insanı çevreleyen dünya birbirine karşıt güçlerin ve yapıların mücadelesi üzerine kuruludur. Bu yapılar ve güçler birbirleriyle etkileşime girerek sentez oluştururlar. Bu sentezde biri diğerine genellikle baskın gelir ya da iki yap1 da aynı potada eriyerek birbirlerine benzeşirler (Tilbe, 2000, s. 34). Bundan yola çıkarak şöyle söylemek mümkün olur:

(Marksçlike;) doğanın, toplumun ve düsüncenin gelişiminin, insanoğlunun tüm maddi ve manevi yaşammm evrensel yasalarm açılarken materyalist diyalektik, iş̧̧ sinffinm ve tüm diğer emekçi halk.n sosyo-politik. ideallerini, amaçlarm ve çkarlarm bilimsel bir doğrultuda formüle etmeyi olanak.l kilar (Krapivin, 1988).

Eytişimsel olmayan, yani Marksçı öğreti dışındaki bütün bilim ve yöntemlerin öznel olduklarına ve gerçekliği saptırdıklarına inanan Goldmann, buna karşın Marksçı incelemelerin büyük ölçüde sınıf kavramına ve ekonomik etkenlere dayandığı vurgusunu yapar. Marx’ın da önemle üzerinde durduğu ekonomik ve politik etkenlerin bir toplumun ya da sınıfın bilinçlenmesindeki rolünü oldukça önemser. Goldmann’a göre, Marksçı düşüncedeki iktisat terimini salt basit anlamıyla değil, toplum içinde nasıl ilişkiler oluşturduğunu, toplumu nasıl şekillendirip etkilediğini temel alarak ele almak gerekir. Çünkü iktisadi yapı toplumun bütün altyapı ve üstyapılarını etkiler, onları şekillendirir.

Goldmann'ın çözümleme yönteminde önemli yer tutan “olası bilinç” konusunda ilk ciddi tanımı Max Weber yapmıştır. Ancak onun tanımlaması nesnel olasılık ve en yüksek bilinç kavramları üzerinde durmadığı gibi, ortaya koyduğu tanım da yeterli değildir. O bu konuya sadece kar-zarar, yani çıkar ilişkisi olarak bakar ve bu konuda daha çok tinbilimden faydalanır. Oysa olası bilinç toplumsal sınıflar arasındaki ilişki sonucu oluşur. Birbirleriyle çatışma halinde olan sınıflar arasındaki ilişki sonucu biçimlenen bilinçtir. Birbirleriyle çatışma halinde olan sınıflar kendi çıkarlarını temel alarak ortak bir bilinç oluştururlar. Bireyden bireye küçük farklılıklar gösterse de grup ya da toplum düzeyinde ortak ve herkesin benimsediği bir bilinçtir. Kişiye göre bazı tutarsızlıklar da gösterebilir. Toplumsal ilişkiler ve yapılar bu bilincin oluşmasında oldukça önemlidir. Bu şekilde oluşan bilincin parçalı olan haline dünya görüşü, daha bütüncül ve tutarlı olan şekline ise ideoloji adı verilir. İdeolojilerin kendi isimleri vardır ve kuramsal çerçeveleri oldukça belirgin ve özgündürler, dünya görüşleri ise çeşitli görüşlerden esinlenir fakat tam anlamıyla bütünlük ve tutarlılıklarından söz edilemez. Birey ve toplum yaşamındaki koşulların iyileştirilmesi, insanın mutluluğu için ortaya konan kuramlar bütüncül ve geniş çevreleyenleriyle düşünülüp tasarlandığ1 için ideoloji niteliğindedirler. İdeolojiler aynı zamanda olabildiği ölçüde tutarlı ve uygulanabilir özelliktedirler. Buna karşıllk birey ve toplum sorunları için bir düşünceye sahip olan her insanın kendine göre şekillendirdiği, öznel ve görece özelliği öne çıkan bir dünya görüşü olur. Dünya görüşü oluşturmak bile bilinçli öznenin ortaya koyduğu bir düşünme eylemi olduğundan hareketle, bireyin gerektiğinde ideolojiler doğrultusunda oluşturduğu dünya görüşüne uygun biçimde eylemde bulunduğuna dikkat çeker:

Karşılıkl ilişkileri olușturmak, işbölümünü düzenlemek için düsünce, kuramsal dünya kaçnılmaz olur ve bunlarn varliğ en basit biçimde de olsa tüm ortak eylemi koşullar. Düsüncenin olduğu yerde ortak eylem, ortak eylemin olduğu yerde düsünce vardır (Goldmann, 1976, s. 22).

İdeolojiler toplumsal sınıfları oluşturur, sınıf içerisindeki bireyin dünya görüşü farklılık gösterse de her birinin ortak özlemleri ve beklentileri vardır. Bu ortak özlemler, beklentiler veya çözüm arayışları ortak bilinci oluşturur. Goldmann’a göre ortak bilinci en iyi şekillendiren, dillendiren veya onu formüle eden toplumun aydınları ve sanatçılarıdır. O halde aydın ve ifade etme yeteneği güçlü olan yazar bu ortak bilinci yazınsal ve düşünsel ürünlerde geniş kitlelere duyurma amacı güder: "Edebiyat ve felsefe, değişik düzeylerde bir dünya görüşünün anlatımlarıdır. Dünya görüşleri de kişisel değil toplumsal olgulardır" (Goldmann, 1976, s. 61).

Goldmann'ın son halini verdiği yazınsal çözümleme yöntemi üzerinde en çok durulması gereken kavramlar anlama ve açıklama aşamalarıdır. Anlama aşamasında incelenmekte olan yapıt eşsüremsel bir anlayışla ele alınır. Yapıtın neden yazıldı̆̆ından çok yapıtın nasıl yazıldığı ve yapıtı oluşturan anlamlı yapıların neler olduğu dikkate alınır. Söz konusu çözümleme biçiminde araştırmacı bütün yazınsal eleştiri yöntemlerinden faydalanabilir. Ancak Goldmann’a göre en sağlıklı ve başarılı sonuçlanı verebilecek yöntemlerden biri yapısalcı inceleme yöntemidir. "Diyalektikçi edebiyat tarihçisinin görevi; içkin bir estetik ayrıştırmayla yapıtın nesnel anlamını ortaya çıkarmak, bu anlamın o dönemdeki iktisadi, toplumsal ve kültürel etkenlerle ilişkisini göstermektir” (Goldmann, 1976, s. 65) diyen Goldmann, Gérad Genette, 
Roland Barthes ve Algirdas Greimas gibi kuramcıların oluşturmuş olduğu içkin estetik çözümleme örneklerini yapıtı incelerken nesnel veriler sağlayan en verimli ve tutarlı çözümleme yöntemleri olarak görür. Yapıtı oluşturan anlatı yerlemlerinin ve anlatı süreçlerinin ortaya konulması yapıtı anlamlandırmakta en başat adımlardandır. Kurgusal evrendeki kişilerin, zamanın, uzamın ve anlatım tekniklerinin anlaşılması yapıtın açıklanmasında oldukça elzem bir rol oynar. Bunun dışında, Marksçı yöntemin gerektirdiği üzere, yapittaki toplumsal yapıların durumu ve varsa aralarındaki mücadelelerini de ortaya koymak gereklidir. Yapıtta yer alan toplumsal yapıların birbirleriyle ilişskilerini eşsüremsel bir düzlemde içkin unsurlar ele alınarak incelenmesi yapıtın büyük yapıt niteliğini kazanıp incelemeye değer olup olmadığını ortaya koyar. Lukács'in benzeșiklike (fr. homologie) olarak adlandırdığı böylesi bir durumda, yazınsal yapıt ile toplumsal gerçeklikler birbirleriyle ne kadar bağdaşırsa yapıt o kadar başarılı olur (Goldmann, 1950, s. 233).

Açıklama aşamasında ise, yazınsal yapıtın neden yazıldığı ve kurgusal evrendeki yansımalarının, tarihsel ve toplumsal gerçekliklerle benzeşim içerisinde olup olmadığının araştırıldığı evredir. Açıklama aşaması, Goldmann'ın yönteminde en çok önem verdiği aşamadır. Bu aşamada toplumbilimsel, tarihsel, siyasal, düşünsel vb. verilerden yararlanılarak yapıtın derin anlamlarının ve toplum veya grup adına eylem yapan bireyaşkın özne konumundaki yazar ya da sanatçı tarafindan şekillendirilen dünya görüşünün açıklaması yapılmaya çalışılır. Marksçı yazınsal kuramları diğerlerinden ayıran en önemli unsur dünyadaki tarihsel ve toplumsal gerçekliklerin üzerinde durmasıdır. Bu gerekçeyle Goldmann'ın açıklama aşaması da Durkheim tarzı, nesnel bir araştırma yapmayı içerir. Ancak dünya görüşü ve bireyaşkın özne gibi olgular bu nesnelliğe engel olur. Çünkü her yazınsal yapıtta bir ideoloji sorunu vardır. Bundan dolayı uygulanan yöntem eytişimsel bir yöntem olarak kabul edilir. "Toplumbilim ancak tarihsel olduğu zaman somut olabilir; bunun gibi, tarih olguları basit bir biçimde belirlemenin ötesine geçmek isterse zorunlu olarak açıklayıcı yani az çok büyük bir ölçüde toplumbilimsel olacaktır”' (Goldmann, 1977, s. 13).

Yazınsal yapıt belirli bir dönemde ortaya çıkan, döneminin alt ve üstyapılarından etkilenen bütüncül ve tutarlı yapıtlardır. Açıklama aşamasında araştırmacının yapması gereken, yapıtın içkin yapılarından yola çıkarak bu yapıları aşkın unsurlarla yani yapıtı çevreleyen dünyayla bağdaştırmaya çalışmaktır. Anlama ve açıklama aşaması birbirinden bağımsız inceleme düzeyleri değildir. Bu iki aşama birbirleriyle sürekli ilgileşim halinde olmalı ve içkin yapılara bağlı kalarak yazınsal yapıt üzerinde tarihsel ve toplumbilimsel bir okuma yapılmalıdır. Aksi halde elde edilen sonuçlar gerçeklikten uzak olacak ve iki aşamada da elde edilen bulgular birbirleriyle bağdaşmayacaktır (Goldmann, 1964, s. 234). Goldmann anlatıda süre gelen tarihten en fazla on yıl gibi bir süre çerçevesinde inceleme yapılmasını önerir. Zira her on yılda bir kuşaklar değişir ve kuşaklar değiştikçe de toplumsal yapılar, olgular ve ideolojiler buna koşut olarak değişim gösterir.

Roman Toplumbilimi (Pour une sociologie du roman) adlı yapıtının "Roman toplumbiliminin sorunlarına giriş" başlıklı bölümünde, Goldmann sorunsal kahramanın, Lukács'dan ve Girard'dan esinlenerek bir tanımlamasını yapmaya çalışır. Bu iki kuramcı da, yazınsal yapıtlar ve toplumsal yapıların birbirleriyle sıkı bir ilişki içerisinde olduklarını savunur. Bu nedenle, gerçek yaşamda bireyin içinde olduğu durum ve mutluluğu elde etmek için yaptığı arayış gibi, roman kahramanı da değerlerini yitirmiş bir toplumda gerçek değerlerin arayışında olan anlatı kişisidir (Goldmann, 1964, s. 26). Ancak gerçek değerlerin veya mutluluğu elde etmenin peşinde olan bu kişinin aradığını bulması mümkün değildir. Çünkü dünya yeni ekonomik ve siyasal dizgeler içinde kişiyi eşyanın ve paranın kölesi durumuna getirmiştir. İnsanlık eski değerlerini kaybetmiş, şeyleşmeyi (fr. réification) öne çıkarmıştır. O halde roman kahramanının çabası boşunadır ve kendisi de sorunsal kişi/kahramandır: Oysa Girard'ın efendi ve köle diyalektiğinde, "arzuladıkları nesneleri zorla elde ettikten sonra bu kişiler gerçek ve kalıcı bir biçimde ganimetlerinin tadını çıkarırlar" (Girard, 2013, s. 143), ifadeleriyle betimlenen antik dönem insanları henüz değerlerini kaybetmedikleri için mutluluğu elde edebilmekteydiler. Lucien Goldmann, Le Dieu Caché adlı yapitının "Dünya görüşleri ve toplumsal sınıflar" adlı bölümünde dünya görüşünün oluşumunda toplumsal sinıfların nasıl ve ne şekilde rol oynadıklarını ayıntıtı bir biçimde açıklamaya çalışır ve bu oluşumu oluşturan alt kavramlardan ve unsurlardan söz eder. Yazınsal yapıtlarda, içinde bulunduğu toplumsal yapının değerlerini reddeden kişiler olduğu gibi iye olduğu sınıfın değerlerini benimseyen olumlu kahramanlar da vardır. Bu kahramanlar çoğunlukla toplumcu gerçekçi kuramın 1şığında yazıla gelmiş yapıtlarda görülür ve bu tür olumlu kahramanlar öğretici ve yol gösterici niteliklidir, insanlar için örnek model işlevini üstlenirler. Bu demektir ki romancı aşkın bir özne olarak sorunların bilincine varır. Örnek ve arayış önerilerinde bulunur. Buna karşın, sorunları çözecek yetkinliğe iye değildir, yapabildiği tek şey yarattığı kahramanları gibi sürekli gerçek değerlerin peşinde koşmaktır (Tilbe, 2010, s. 28). 
Sonuç olarak Goldmann, eleştiri ve çözümleme konusunda yazınsal türler arasında en çok roman üzerine odaklanır. Çünkü romanı tüm türler arasında gerçekliğe en yakın, toplum bilincini en bütüncül ve tutarlı şekilde yansıtabilen ve üzerinde bilimsel çalısma yapılabilecek en uygun tür olarak görür. Bütün büyük nitelikli yapıtların bir dünya görüşünü yansıttığını savunur. Ona göre bu türden yazınsal yapıtlar ortak bilinci su yüzüne çıkarır ve bunu aydın sıfatındaki bir bireyaşkın özne aracıllğıyla gerçekleştirir (Goldmann, 1962, s. 64).

\section{Anlama Aşaması: İçkin Çözümleme}

Emile Zola'nın Emek adlı yapıtını Lucien Goldmann'ın oluşumsal yapısalcı eleştiri yöntemiyle mercek altına yatırmanın, yöntem gereğince, ilk yolu, yapıtın metin düzleminde anlaşılmasını sağlamaktır. Bu nedenle metin dışına çıkmadan, metni oluşturan yapıları belirlemek gereklidir. Bu bağlamda çözümlemenin bu aşamasında metni oluşturan anlatı yerlemlerinin incelenmesi kaçınılmazdır. Metni oluşturan içkin anlamlı yapıları, yani anlatım süreçlerini, bakış açlarını, kişileri, zamanı, uzamı, bir anlamda roman metninin oluşmasına katkı veren öğelerin saptanması elzemdir.

\section{Anlatım Teknikleri}

Doğalc1 yazınsal akımın öncülerinden Émile Zola, kaleme almış olduğu bütün yapıtlarda bu akımın ilkelerine her zaman sadık kalır. Toplumu ve insanı fiziksel koşullarıyla ve bir doğa bilimci gibi ele almak niyetinde olan yazar, gözleme, deneye, belgelemeye ve ankete başvurur. Yazar, insanı ve toplumu oluşturan bütün öğe ve anlamlı yapıları incelemek ve anlamlandırmak gereksinimi duyar. Doğalcı bir yazar olarak evrensel gerekircilik, Prosper Lucas'ın kalıtım üzerine yaptı̆ğ çalışmalar, Claude Bernard'ın deneysel hekimliği, Darwin'in doğal seçilim, doğal ortam ve yaşam için mücadele kavramları, Taine’in ırk, ortam ve çağ kavramları gibi kavram ve çalışmalardan esinlenerek yapıtlarını oluşturur. Anlatıları kişsisiz (fr. impersonnel) bir bakış açısıyla ilerler. Zira yazar insana ve topluma dair her şeyi, bir böceği bile kendi doğal ortamında inceleyen bir doğa bilimci gibi incelemek ve elde edilen her veriyi bulguya dökmek niyeti taşır (Zola, 1881, s. 228).

Bu doğrultuda, kaleme aldığ1 yapıttaki anlatı yalnızca yansıtma görevi üstlenmez, yazar aynı zamanda yapıtında gerçekliği yeniden oluşturur. Onun yapıtıyla ilgili yapısalcı bir okuma, yazarın oluşturduğu yapıtın ayırıcı, özgün ve ayrıcalıklı özelliklerini ortaya koymakta başat bir rol oynar. Yapıtın içeriğini dişa vuran anlatıcı, okura anlatıyı aktaran yalnızca dilsel bir özelliktir ve ancak sözcüklerle var olur. Doğaldır ki her zaman anlatıyı ve odaklanmayı gerçekleştiren anlatıcı değildir. Anlatı ve odaklanmayı birbirinden ayırabilmek için kim konuşuyor? (anlatan) ve kim görüyor? (keşfeden) sorularını sormak gerekir (Raimond, 2008, s. 132).

Zola, yapıtın genelinde üçüncü tekil şahıstaki anlatıyı tercih eder. Anlatıcı olaylara tamamen tanrısal bir bakış açısıyla bakar. Sufır odaklayımla (fr. focalisation zéro) nesneler ve özneler hakkında herkesten daha çok şey bilir ve görür. Bu sayede okur, roman karakterlerinin özü ve davranışlarının kaynağı hakkında her türlü bilgiye sahip olur. Yazar anlatının dışındadır, bundan dolayı anlatı elöykëisel (fr. hétérodiégétique) niteliklidir. Anlatıcı anlatı boyunca nesnel bir anlatımı sürdürdüğü gibi ilerleyen bölümlerde izlenimci anlatım tavrı da gösterir. Anlatıc1 rolünü üstlenen yazar, kendi dünya görüşünün haklıllğını okura kanıtlamak niyeti taşır. Anlatıcının düşünceleriyle roman başkişisinin düşünceleri arasında ciddi bir koşutluk vardır. Anlatıcı onun eylemlerini ve düşüncelerini zaman zaman onaylar. Bundan dolayı yazar çoğu kez kendini anlatıcı olarak gösterir. Anlatı boyunca roman karakterleri arasında geçen çok sayıda karşlıklı konuşma sayesinde kişilerin düşüncelerini ve duygularını doğrudan kişilerin ağzından vermeyi yeğler, konuşmalar doğrudan anlatım (fr. discours direct) tekniğiyle okura aktarllır. Bununla birlikte karşl1klı konuşmalar sırasında odaklayım birinci tekil şahısta benöyküsel (fr. homodiégétique) anlatı halini alır.

Diyaloglar yazınsal yapıtların sıkça kullandığı bir anlatı yöntemidir ve içerikleriyle konuşmacıların kişilik özellikleri ve dünya görüşleri hakkında okura önemli bilgiler verirler. Anlatıya değişik bakış açıları kazandırır ve okuru anlatının derinliğine çekerler. Doğalcı romanlarda konuşmalar aracilığılla halkın psikososyal durumuyla ilgili önemli bilgiler aktarılır. Zola'nın Emek'inde diyalog türlerinden olan özellikle tiyatroda kullanılan tirad ve stikomitik konuşma örneklerine de yer verilir. Tirad biçimindeki konuşmalarla kişinin dünya görüşü okurlar için anlaşılır hale getirilir. Anlatıdaki bu tarz konuşmalar neredeyse bir nutuk şeklindedir. Bu konuşmalar yapısal olarak uzun, etkili ve ustalıkla yapılandırılmış türdendir. Zola, yapısal olarak kısa ve oldukça hızlı gelişen bir diyalog türü olan hüzünlü ve trajik olup şïrsel ifadelerin kullanıldığ1 konuşmaları (stikomitik) daha çok duygu yoğunluğunun olduğu bölümlerde kullanılır. 
Romanda anlatıcının yönetme ve yorumlama diye iki temel işlevi vardır (Raimond, 2008, s. 119). Bu demektir ki, anlatı içinde gelişen olayların bir düzen içinde verilmesini veya öykülenen olguların anlaşılmasını anlatıcı gerçekleştirir. Algirdas Greimas ve Paul Larivaille, anlatıcının işlevlerini temel alarak, anlatım sırasındaki durum değişiklikleri beşli şema adıyla bir inceleme örnekçesi oluşturur. Onlara göre anlatıların tümü beş önemli evreden oluşur. Bu şema esas alınarak Emek’in anlatısına bakıldığında aşağıdaki türde değişikliklerin olduğu göze çarpar:

Tablo 1. Anlatımm Yapısmı Cö̌zümlemek İ̧in Önerilen Beşli Şema

\begin{tabular}{|c|c|}
\hline $\begin{array}{l}\text { Başlangıç veya } \\
\text { yönlendirme durumu }\end{array}$ & $\begin{array}{l}\text { Anlatının yeri, dönemi, kişileri gibi öğeler aracılığıyla anlatının yönlendirildiği ve } \\
\text { anlaşılmasının sağlandığı aşamadır. Emek'te toplumsal sınıflar arasındaki eşitsizlik had } \\
\text { safhadadır. Özellikle işçilerin yaşam ve çalışma koşulları oldukça kötüdür. }\end{array}$ \\
\hline $\begin{array}{l}\text { ya } \\
\text { nplikasyon }\end{array}$ & $\begin{array}{l}\text { Bir engelin, sıkıntının veya başlangıçtaki dengeyi bozan bir olgunun ortaya çıktığı } \\
\text { aşamadır. Romanda sınıflar arasında her alanda eşitlik koşullarının sağlanmasına } \\
\text { yönelik eylem ve örgütlenmeler, hak arayışları başlar. }\end{array}$ \\
\hline Dir & $\begin{array}{l}\text { Belenmedik şeylerin olduğu ve olayların vardığı son noktayı içeren evredir. Romanın } \\
\text { sorunsalı durumundaki toplumsal eşitsizliği gidermek için alternatif toplum modelleri } \\
\text { denenir. Bu bağlamda ütopik sosyalizmin önerdiği küçük eşitlikçi toplum birimi } \\
\text { kurulmaya çalışılır, ancak çıkarlarının zarar göreceğini düşünen burjuvalar engelleme } \\
\text { girişiminde bulunur. }\end{array}$ \\
\hline Çö & $\begin{array}{l}\text { Eksikliğin giderildiği veya sorunun çözüme ulaştığı evredir. Zorlu bir mücadeleden } \\
\text { sonra ezilen halk kitlesi eşit yaşam ve paylaşımın olduğu istediği türden bir } \\
\text { beldeyi/komünü kurmayı başarır. }\end{array}$ \\
\hline Son $\mathrm{d}$ & $\begin{array}{l}\text { Dengelerin yeniden kurulduğu ve olayların vardı̆̆ı son noktayı içeren aşamadır. } \\
\text { Komün kurulmuş ve benzer komünlerin kurulması dünyanın dört bir yanına çeşitli } \\
\text { yollarla yayılmaya başlamıştır. }\end{array}$ \\
\hline
\end{tabular}

\section{a. Zaman}

Her tür roman anlatısı belirli bir zaman aralığında geçer. Anlatının geçtiği zamanın belirli belirteçlerle vurgulanması anlatıdaki nesnel zamanı gösterir. Bir durumdan başka bir duruma geçişin anlatısı da öyküleme zamanıdır (Özdemir, 2000, s. 151). Emek adlı romanda anlatı zamansal olarak, geçmişten başlar, şimdiye taşınır ve geleceğe doğru ilerler. Zaman sürekli olarak okura hatırlatılır. Anlatının başlarında olayın gerçekleştiği zamanla ilgili belirteçler oldukça kesindir. Fakat anlatı ilerledikçe zaman kavramı oldukça silikleşir ve anlatı gelecek bir zamana taşınır. Geçmiş zaman belirteçleri kullanılarak her şeyi bilen bir anlatıcı tarafından olaylar okura öykülenir. Bilinen (di'li) geçmiş zaman (fr. passé simple) ve şimdiki zamanın hikâyesi (fr. imparfait) anlatının tamamında hâkimdir. Artsüremsel zamanın kullanılmasıyla anlatının uzun bir süre önce gerçekleştiği, ancak etkisinin hala sürdüğü hissi verilir (Herschberg Pierrot, 2003, s. 78). Şimdiki zamanın hikâyesi özellikle olay, uzam ve insan betimlemelerinde kullanılır. Geçmişe yönelik betimleme yoluyla değişimini sürdüren olgulardan bahsedilir. Zaman zaman anlatıcı ve roman başkişisi geleceğe yönelik olayları ve fikirleri Fransızcada geçmişteki gelecek zaman olarak kullanılan şimdiki zaman şart kipiyle (fr. conditionnel présent) önceler. Çünkü anlatıcı, roman kişilerinin eylemlerini gerçekleştirmesinden sonra olayları aktarır. Karşılıklı konuşmalar, bilinç akışları ve betimlemeler sırasında anlatı oldukça yavaş ilerler. Olayların öykülenmesinde ise zaman oldukça hızlı akar. Yapıtı oluşturan unsurları daha açı bir şekilde ortaya koyabilmek için, anlatıcı geriye sapım (fr. analepse) ve öncelemelere (fr. prolepse) başvurur. Bunun dışında anlatıda öz̧etleme (fr. ellipse) ve duraklama (fr. pause) gibi yöntemler de kullanılır. Bu sayede okur, olaylar ve kişiler hakkında daha kesin bilgilere ulaşma olanağ1 elde eder. Romanın başkişisi Luc, kent soylularla yaptığı tartışmalarda toplumcu ülkülerinden ve gelecekte kurulacak herkesin eşit olacağı komün tarzı bir yerleşim alanından (fr. phalanstère) ve yenidünya düzeninden söz eder. Başkişi işleviyle anlatıda kehanet sahibidir, her şeyi bilir ve anlatı önsüremsel (fr. prophétique) bir zamana oturur. Yeri geldiğince Raimond da belirttiği üzere romanda geleceğe yönelik ve karmaş1k yöntemler kullanılır ve ütopik dünyadaki iyiler ve kötüler arasındaki mücadele anlatılır (Raimond, 2008, s. 32). Anlatıdaki olayların geçtiği tarih kesin olarak belirtilmez, ancak bununla ilgili birçok ipucu bulmak olasıdır. Sœurette 1852 yılından on yıl sonra dünyaya gelir. Anlatının başında yirmi beş yaşındadır. Dolayısıyla anlatı 1880 ile 1890 yılları arasında yaşanmış olayların öykülemesini yapar. Onunla aynı yaşta olan Luc, romanın sonunda seksen beş yaşında yaşamını kaybeder. Dolayısıyla anlatı süresi altıış yıl sürer. Yapıtın üçüncü ana bölümünden itibaren anlatı tamamen ütopik bir uzama yerleşir. Bundan dolayı zaman belirteçleri de masallarda olduğu gibi oldukça belirsizleşir. 


\section{b. Uzam}

Uzam, anlatı kişilerini okura daha bütüncül olarak aktarabilmek için kullanılan bir anlatı öğesidir. Anlatıda uzam farklı biçimlerde kendini gösterebilir. Öyle ki, uzam tamamen kurgusal olabileceği gibi parçalı bir gerçekliğe de sahip olabilir. Ayrıca olaylara ve kişilere göre uzamlar esenlikli (fr. euphorique) ya da esenliksiz. (fr. disphorique) bir hal alabilir. Gerçekçi yazarlar gibi doğalcı yazarlar da gerekircilik kanununu temel alarak, uzam, nesneler ve kişiler arasındaki ilgiyi ortaya koymak amaciyla betimlemeye oldukça fazla önem verirler. "Betimlemeler, durumlar ve koşullar hakkında bilgi verir. Nesnelerin ve mekânların biçim, hacim ve içerik birleşimleriyle ilgili bulguları aktarır. Aynı zamanda kişilerin toplumsal ve tinsel düzeyleriyle ilgili verileri sunarlar"'( Schmitt ve Viala, 1982, s. 67).

Bu bağlamda Emek adlı romanda gerçek yer adları olduğu gibi, yazarın izlenimciliğine dayanarak adlandırılmış yerler de vardır. Yapıttaki anlatı Beauclair adındaki bir uzamda geçer. Buradaki uzamların genel durumu toplumsal sınıfların durumlarıyla aynıdır. İşçi ve köylü sınıfının bulunduğu yerler oldukça esenliksiz, kent soyluların bulundukları uzamlar da oldukça esenliklidir (Zola, 2010, s. 6). Bir uzam olarak Abîme adlı fabrikanın adı Türkçeye dipsiz uçurum olarak çevrilebilecek eğretisel bir anlam taşır. Abîme, tam anlamıyla işçilerin her gün yaşamlarını tehlikeye attıkları bir cehennemsi bir uzamdır. Ĕ̆retisel olarak tam anlamiyla bir canavara benzetilen Abîme (Zola, 2010, s. 55-56), işçilerin yabancilaşmalarına neden olan en önemli merkezdir. İşçiler her gün burada eziyet görür ve burası sefaletin odak noktasıdır.

Brias Sokağının anlatımında toplumun her kesiminden insanı görmek olasıdır. İşçilerin ve köylülerin sefaleti her yerde aynıdır. Crêcherie'nin isimlendirilmesi yeniden doğuşu, adaleti ve umudu anımsatır (Zola, 2010, s. 56). Luc ve Jordan'ın Fourier ve Saint-Simon'un düşüncelerinin 1şı̆̆ında kurduğu bu yer işçilerin ve emeğin kurtuluşu ve yeniden doğuşunun anavatanı olmak iddiasındadır (Zola, 2010, s. 223). Zola, anlatısında bir araştırmacı ciddiyetiyle nesnel betimlemeye, bazen de nesnelerin kendi duygularında yarattığı izlenimlerinden yola çıkarak öznel betimlemeye başvurur. Gerçekle ideal arasında bir bağlantı kurmak ister. Hem ideal ütopik bir toplum betimlemesi yapar, hem de onu bilimsel temellere oturtmaya çalışır. Zola'nın örnek aldığ1 Fourier tarzı ütopya, insanı insan yapan duygu ve tutkuları özgürleştirmeyi amaç edinir. Hedef her bireyin kendi güç ve yeteneklerini keşfetmesini sağlamanın yanında, toplumsal düzeni tutkuların özgür bir şekilde gerçekleştirilebileceği biçimde oluşturmaktır. Bu ilkelerle oluşturulacak phalanstère diye adlandırılan ortak yaşam alanının (fr. commune) amacı, diğer bölgelerle bağlantı kurup yaygınlaşmaktır. Bu nedenle phalanstère kapalı bir ortak yaşam alanı değil, aksine dışa açık ve yaygınlaşması istenen bir toplum düzenidir.

Ütopya yazarları düşledikleri ideal toplumu genellikle yurttaşların yaşadığı yaşam alanlarıyla betimlerler. Amaçları, yenilenmiş bir yaşam ve sanayi kenti sunmaktır. Buna karşıllık bilim-kurgu türünden yapitlar ise geleceğe yönelik yeni fikir ve yaşam şeklinin ortaya konduğu tarihsel roman gibi okunan öncelemelerdir. Ütopya, bilim ve uygulayımı siyasetle ulamlar. Ütopyalar ve öncelemeler, hem yaşanılan dönemi eleştirir hem de geleceğe 1şı tutma özelliğine sahiptir. Bundan dolayı ütopyaların pozitif bilimlerle yakın ilişkide olduklarını söylemek olasıdır.

Romanda uzamsal açıdan birbiriyle karşılaştırmaya olanak veren zıtlıklar içeren uzamların anlatısı Özellikle verilmiştir. Buna göre, oluşturulan yeni düzenle eski düzen arasındaki uzamsal değişim bir tabloyla şu şekilde gösterilebilir:

Tablo 2. Roman kurgusunda eski ve yeni düzen arasindaki uzamsal değisimler

\begin{tabular}{ll}
\hline Abîme (Eski düzeni simgeleyen uzam) & Crêcherie (Yeni düzeni simgeleyen uzam) \\
\hline $\begin{array}{l}\text { Ekonomik açıdan, sınıflar arasındaki eşitsizlik } \\
\text { oldukça büyüktür ve bu uzama yansır. }\end{array}$ & $\begin{array}{l}\text { Ekonomik açıdan, sınıflar arasındaki eşitsizlik kaybolur ve } \\
\text { refah seviyesi yükselir. }\end{array}$ \\
\hline $\begin{array}{l}\text { Eğitsel alanda, işçilerin durumu oldukça kötüdür } \\
\text { okullar zenginler için vardır. }\end{array}$ & $\begin{array}{l}\text { Eğitsel alanda, çocuklar temiz ortamda eğitim alır, teorik } \\
\text { ve pratik bir arada yürütülür. }\end{array}$ \\
\hline $\begin{array}{l}\text { Toplumsal alanda, işçilerin sosyalleşecek alanları } \\
\text { oldukça azdır genellikle meyhaneler tercih edilir. }\end{array}$ & $\begin{array}{l}\text { Toplumsal alanda, insanlar kültürel ve sportif etkinliklere } \\
\text { katılır ve meyhaneler kaldırılır. }\end{array}$ \\
\hline $\begin{array}{l}\text { Çevresel alanda, çalışma ve yaşam ortamı oldukça } \\
\text { sağlıksız, bakımsız ve tehlikelidir. }\end{array}$ & $\begin{array}{l}\text { Çevresel alanda, çalışma ve yaşam ortamı oldukça sağlıklı, } \\
\text { bakımlı ve güvenlidir. }\end{array}$ \\
\hline $\begin{array}{l}\text { Hukuksal alanda, mahkemeler ve emniyet güçleri } \\
\text { kent soyluların çıkarlarını korumak için vardır, halka } \\
\text { kötü davranılır. }\end{array}$ & $\begin{array}{l}\text { Refah seviyesi yükselen toplumda mahkemeler ve emniyet } \\
\text { güchintiyaç kalmamıştır. }\end{array}$ \\
\hline
\end{tabular}




\section{c. Kişiler}

Yazarın doğalcı kuram çerçevesinde olușturduğu yazınsal yapıtlarında kișiler, yașamış olduğu toplumdaki olası bilinç yapılarının temsilcisidirler. Yazar, yaşamış olduğu toplumdaki insan betilerini bedensel ve toplumbilimsel olarak inceler. Oluşturmuş olduğu her beti toplumda var olan belirli bir toplumsal ve tinsel bilinç bütününün temsilcisi durumundadır. E. Özdemir'e (1999, s. 253) göre, "yazar, gerçekten aldıklarını kendi kişiliklerinin hamuruyla yoğurur, biçimlendirir. Gerçek insanla kan bağı olmayan, insana özgü niteliklerden, edimlerden yoksun roman kişilerini yadırgarız çoğu zaman.” Lukács’a göre tipler yaşamış oldukları toplumun ve tinsel dünyalarının eytişimsel bir ürünüdürler, var oldukları toplumsal yap1 ve çevreyle bir bütün oluştururlar (Lukács, 1987, s. 256). Tip, toplumbilimsel ve tinbilimsel verilerin bir bütünüdür. Söz konusu olan, belirli bir dönemde gözlenmiş örnek toplumsal gerçekliklerdir (Schmitt \& Viala, 1982, s. 72). Zola yapıtlarında oluşturduğu anlatı kişilerini genellikle bu doğrultuda oluşturur ve bu yapıtındaki kişiler de iye oldukları toplumsal yapının ve çevrenin aynı zamanda gerekirciliğin birer ürünüdürler. Yapıttaki kişi kadrosu oldukça çeşitlilik gösterir. Toplumun her kesimini ve toplumsal yapılarını, dönemin ülkülerini ve tinsel durumlarını temsil eden bireyler romanda kendilerine yer bulur. Emek, kişiler düzleminde, Fransız toplumunun insan ansiklopedisi gibidir.

Anlatının başkarakteri olan Luc, toplumcu öğretilerin güdümünde olan bir mühendistir. Dönemin en mühim toplumcu düşünürlerinin sözcüsü ve savunucusu görevini üstlenir. Toplumda gözlemlemiş olduğu yozlaşmay1 ve eşitsizliği vahşi anamalcllı̆a bağlar ve toplumu Fourier, Saint-Simon ve diğer toplumcu ve anarşist düşünürlerin ülküleri ışığında kurtarmaya çalışır (Zola, 2010, s. 181). Luc'un bir mühendis olmas1 işçi sınıfını ve kent soylu sınıfı en iyi şekilde gözlemleyebilmesine olanak verir ve mesleğinin getirdiği saygınlık sayesinde insanlar üzerinde daha inandırıcı olur. Toplumdaki yapısal ve düşünsel değişiklik önerileri, lider yeteneğindeki Luc tarafından topluma sunulur. Liderin değiştirmek istediği toplumu ve kültürü iyi bilmesi gerektiği için, romanın ilk yarısında toplum uzunca gözlemlenir. Toplumsal sorunlar içinde bocalayan emekçi halk, toplumsal koşulları düzeltmek ister, ancak bunu gerçekleştirebilecekleri kuramsal bir altyapıları yoktur. Luc onlara bunu sağlar ve bunu gerçekleştirebilmeleri için onlara maddi ve manevi destek verir. Adbilimsel (fr.onomastique) açıdan bakıldığında adı bile "aydın" ve "yol gösteren" anlamı taşır.

Jordan adlı roman kişisi de kurulacak olan phalanstère'de oldukça önemli rol oynar ve Luc kadar önem taşır. Sürekli bilimsel çalışmalar yapan, kendini insanlığa adamış ve laboratuvarından çıkmayan bir bilim adamı niteliğindedir. Fosil yakıtlarla çalışan sanayi makineleri yerine, temiz enerjiyle çalışan makinalar yapmak ve kas gücünü azaltmak en büyük hedefidir.

Ragu ise, yapıtta yer alan karakterler arasında yabancılaşmış işçilerin tipik örneğidir. Sınıf bilincine sahip değildir ve her ne kadar işverenleri eleştirse de ikiyüzlü tavırlar sergiler. Sınıf bilincine sahip eylemci meslektaşlarıyla alay eder ve onları yerer. Kolay yollardan zengin olmanın peşindedir (Zola, 2010, s. 13). Yapıtın ilerleyen bölümlerinde kurulmak istenen yeni komüne karşı cephe alır. Luc'u öldürmeyi dener, ancak başarısız olur. Yapıtın son bölümünde toplumcu komün kurulmuştur ve Ragu yaptıkları için pişmandır, ne var ki geri dönmeyi kendine yediremez.

Kentsoylu sınıfa mensup Boisgelin, asalak gibi yaşayan bir tiptir. Tembel, başkalarının sırtından geçinen ve yaptığı her işte başarısız olan bir anlatı kişisidir. Yaşamında yaptığı en iyi şey para harcamak, eğlenmek ve insanlardan para koparmaktır. Yaşamı boyunca hiçbir işte çalışmaz ve okulu bile zor bitirir. Abîme, yanıp kül olduktan sonraki tek endişesi sahip olduğu ayrıcalıkları koruyabilmektir. Bundan dolayı Luc'le bir anlaşma yapmaya çalışır, ancak bu gerçekleşmez. Boisgelin, Crêcherie'deki yaşam biçimine uyum sağlayamaz. Zola, onun kalıtsal özelliklerini öne çıkararak biyoloji alanında bilinen kalıtım yasasına bir göndermede bulunur (Zola, 2010, s. 200).

"Yardımsever" anlamı taşıyan Bonnaire adlı kişi, sınıf bilincine sahip ilerici ve devrimci bir tiptir. Sınıfinın ilerici ülküsündeki sorumluluğunun bilincindedir ve gelecekten umutludur (Baysan, 2010, s. 4). Yardımlaşma ve dayanışma onu tanımlayan en önemli nitelikleridir. Meslektaşları tarafindan sevilir ve saygı görür. Yapılan grevlerin ve oluşturulan yeni komünün liderlerindendir.

Josine ise, sömürülen ve aşağılanan iş̧̧i tipinin en iyi örneklerindendir. Aynı zamanda yapıtın neredeyse tamamında erkekler tarafindan baskılanan kadınların temsilcisi durumundadır. Kadın tipler ikincil niteliklere sahip, silik ve etkisizdirler. Yeni düzenle birlikte bu durum değişir. Josine, anlatının son bölümünde Luc ile evlenir ve çocukları olur. 
Önem arz eden diğer kişilikleri de kısaca sıralamak gerekirse, Nanet, sömürü dizgesinin en genç kurbanlarındandır. Anlatının başında altı yaşındadır, ancak yeni düzende en büyük umutlardan biri olur. Lunot Baba, yabancılaşmış ve sömürülmüş işçi tipinin en acıklı örneğidir. İnsanlık dışı çalışma koşullarının en belirgin kurbanıdır. Delaveau, fabrikanın en buyurgan ve baskıcı yöneticisidir. Başkaldırıya asla tahammülü yoktur. Var olan düzenin en kat1 koruyucusudur. Sœurette, Jordan'ın kız kardeşidir. Yapıtta oldukça etkisiz görünmesine rağmen $\mathrm{o}$, Luc’un kadın hali gibidir. Dünya görüşleri ve kişilikleri başkarakterle aynıdır. Luc'u Beauclair'e gelmeye o ikna eder ve o da aynı toplumcu öğretilerden esinlenir (Baysan, 2012, s. 2). Hermeline, anlatıda çok küçük bir role sahiptir. Rahip Marle ile giriştikleri bir tartışmada dinin, eğitim ve devlet kurumları üzerindeki olumsuz etkisinden bahseder ve olguculuk ile laikliğin savunuculuğunu yapar. Ona göre dinsel bütün kurumlar ortadan kalkmalıdır. Madam Mitaine, bir kent soyludur, ancak toplumcu bir bilince sahiptir ve işçilere yardım eder. Abîme mülkünün sahibi Mösyö Jérôme, hasta yatağındayken bütün sermayesinin ve mülkünün insanlara dağıtılmasını ister çünkü bunlar aslinda herkese aittir.

Greimas, anlatı kişilerinin ne olduklarına göre değil ne yaptıklarına göre ele alan bir model sunar ve bunun adını "eyleyenler modeli" olarak adlandırır. Ona göre kişiler birer eyleyen (fr. actant) olarak işlev görür. Bu eyleyenler gönderici, alıcı, özne, nesne, engelleyici ve destekleyici olmak üzere alı farklı işleve sahiptirler. Ancak her eyleyen aynı anda birden fazla işleve sahip olabilir. Gönderici özneyi harekete geçiren olgular ya da olaylardır. Alıcı ise varılan sonuçtur. Özne, arzulayan ve amaçlayan görevindedir. Nesne aranılan ve istenilen şeydir. Destekleyici özneye yardım eder. Engelleyici ise ona engel olmaya çalışır (Yücel, 1982, s. 102-103). Greimas'ın eyleyensel modeli'ne göre Emek adlı romanın kişi işlevlerini şu şekilde tespit etmek olasıdır:

Tablo 3. Anlatı kişilerinin göstergebilimsel işlevleri

\begin{tabular}{ll}
\hline Gönderici & Siyasi yapı, fakirlik, anamalcılık, sömürü, yabancılaşma, insansızlıklaşma \\
\hline Alıcı & Özgürlük, toplumculuk, kutsallaştırma, emeğin özgürlügü, toplumsal düzen \\
\hline Özne & Luc, Jordan, Bonnaire, işçi ve köylü sınıfı \\
\hline Nesne & Özgürlük, toplumcu düzen, refah, teknolojik atılım, laik eğitim \\
\hline Destekleyici & M. Jérôme, Sœurette, Josine, Hermeline, Yvonnot'lar, Morfain, Lunot baba \\
\hline Engelleyici & Kent soylular, bilinçsiz işçiler, yargıç Gaume, Yüzbaş1 Jollivet, rahip Marle \\
\hline
\end{tabular}

\section{d. Toplumsal Yapılar ve İlişkiler}

Goldmann'ın oluşturduğu inceleme yönteminin odak noktalarından bir diğeri, toplumsal sınıfların durumunu ve sınıflar arasındaki çatışmayı tespit etmektir. Çünkü insanın mensubu olduğu toplumsal sınıf, onun bilinçlenmesinde oldukça önemli rol oynar. Bu anlayış Zola'nın doğalcı anlayışında da görülür. Kentsoylu ve emekçi sınıfın özümsediği ekinsel değerler bilinçli uygulanmayan icgüdüsel ekin (fr. culture instinctive) olarak adlandırlabilir. İçine doğmuş olduğu çevre ve ortam onu şekillendirir ve bir dünya görüşüne sahip olmasını sağlar. Toplumu oluşturan bireyler belirli iktisadi, siyasi ve toplumsal ortak hedeflere ulaşmak için kendi içlerinde bir işbirliği oluşturup toplumsal ilişkilere girişir. Bundan toplumsal sınıf kavramı ortaya çıkar. Bir toplumsal sınıfa iye olan bireyler genelde benzer alıskanlıklar, tepkiler ve beklentilerle iç içedirler (Dönmezer, 1994, s. 136-139). Toplumdaki bazı kişiler maruz kaldıkları normları kabul etmez ve toplumbilimde sapma (fr. déviance) denen başka şekilde davranış biçimi geliştirirler. Romanın bazı kişileri, özellikle başkarakter Luc, mensubu olduğu sınıfın ekinsel ve yapısal değerlerini reddederek sapıcı eylemlerde bulunur. Bir kentsoylu olmasına karşın işçilere yardım eder. Bunun aksine romanda, işçi sınıfına mensup olmasına karşın kentsoylulara hizmet eden işçi kişilikler de vardır.

Luc, toplumcu düşünürlerin yapıtlarını okuyarak yeni bir düzenin oluşturulabileceğine inanır ve bunu gerçekleştirebilmek için harekete geçer. Başlangıçta barışçl yollarla kurulmak istenen yeni komün, kent soylular tarafından çok ciddi derecede baskılanır. Yeni komünün kurulması aşamasında içerden ve dışardan birçok olumsuzluk ortaya çıkar. İşçi sınıfı uzun zamandır girişmiş olduğu grevler yüzünden oldukça zayıf düşmüş ve kent soylular onlara hiçbir şekilde hoşgörülü davranmaz. Öyle ki, anlatının ilk yarısında işçilerin bu durumu oldukça acıklı bir tabloyla okuyucuya sunulur. Kent soylular ise şatafat içinde yaşar ve anlatıcının onlarla ilgili yorumları ve yansıtmaları oldukça yericidir. Yapıtın ikinci kitabının sonuna kadar sınıf çatışmaları had safhadadır. Üçüncü kitaptan itibaren sınıflar kaynaşır ve sınıfsız bir toplum oluşur. Toplumda hızlı bir yenileşme hareketi gerçekleşir ve bunun sonucunda bazı kişiler gerçekleşen değişikliklere uyum sağlamakta zorlanır. Kent soylu sınıftan bazı kişiler yeni düzene uyum sağlayamadığ1 gibi, işçiler arasında olup da uyum sağlayamayanlara da rastlanır. Bu tür değişimlerin yaşandığı ortamda, bazı kişiler toplumla bireyin bağının kopması anlamındaki anomi durumunu yaşar ve bu durum onların içsel 
dünyalarında ölüme kadar sürükleyebilen ciddi bir bunaltı yaratır. Yapıttaki Morfain kişisi böylesi bir duruma oldukça iyi bir örnek oluşturur (Zola, 2010, s. 196).

Emekçi halkın yaşam ve çalışma koşullarındaki sefalet, işverenlerin çalışanlara karşı takındığı insanlık dışı tutum, yazarı ütopyacı toplumcu düşünceye yönlendiren başlıca nedenlerdir. İşverenler, kendilerine göre hiçbir hakka sahip olmayan emekçileri bir meta olarak görür ve onlara karşı oldukça insafsızca davranırlar. Ekonomik ve siyasal anlamda toplumun üst tabakasını oluşturan bu sınıf çıkarlarını koruyabilmek adına her türlü yasa dışı ve şiddet içeren yola başvurabilecek güç ve bilince sahiptir. Bu ayrıcalıklarını koruyabilmek için süregelen dizgenin devamlılığını gerekli görürler. Devletin bütün kurumları onlara hizmet eder (Zola, 2010, s. 122-123). Bu gerekçelerle, anlatıda kent soylulara yönelik göndermeler ve veriler oldukça eleştirel biçimde verilir.

Isş̧ilerin çalışma ortamı ve yaşam koşulları oldukça kötüdür. Yapmakta oldukları işler oldukça tehlikeli ve çalşsma yerleri son derece sağlıksızdır (Zola, 2010, s. 55-56). Çoğunluğu ağır ve tehlikeli işlerde yaşamlarını kaybederler. Yaşamda kalanlar ise her geçen gün biraz daha ezilirler. Romanda ortaya konan toplumsal betimlemeler XIX. yüzyıl Avrupa'sının tipik bir insanlık portresidir. Ekonomi ve işçi dünyasıyla ilgili roman içeriğinde Marx öğretisine ait pek çok kavramı görmek olasıdır. Yabancılaşma, fetişizm, insansızlıklaşma, şeyleşme, mülksüzleştirme ve sermaye birikimi gibi kavramlar bilinçli olarak yazarın kullandığ1 terimlerdir.

Romanda, üretilen her nesnenin bir kullanım değeri olduğuna vurgu yapıllırken, üretimde en büyük paya sahip işçi veya köylü emeğinin görmezden gelinmesi işçi ve köylü sınıfının yaşamış olduğu sefaletin temel nedenlerden biri olarak gösterilir. Nesnelerin yararının göz ardı edilip olduklarından daha değerli kabul görmesi fetişizmdir. Sahip oldukları araçlarla ayrıcalıklı bir yerde görülmesini sağlayan kent soylu sınıfı ayrıcalıklı hale getiren de fetişizmdir. Sermaye birikimi ise anamalcılığın en önemli silahıdır. Kar elde etmek için yatırılan paraya dayalı dizge, başkalarının sömürülmesine yol açar. Ancak yeni ütopyacı toplumcu düzenle birlikte üretim araçları mülksüzleştirilir ve iktisadi eşitlik sağlanır. Romandaki eski ve yeni düzen boyutlarında birey ve toplumun sahip olduğu ekonomik ve siyasal hak ve özgürlükleri ele almak gerekirse şöyle bir tabloyla karşılaşmak olasıdır:

Tablo 4. Eski ve yeni düzen yapilarmin karşılaștırlması

\begin{tabular}{|c|c|}
\hline Eski Düzen & Yeni Düzen \\
\hline $\begin{array}{l}\text { Siyasi alanda bireycilik, merkantilizm ve rekabet } \\
\text { esastır. Siyasi makamlar için başat olan var olan } \\
\text { düzeni ve kent soyluların ayrıcalıklarını } \\
\text { korumaktır. }\end{array}$ & $\begin{array}{l}\text { Siyasi alanda toplumculuk, dayanışma ve yardımlaşma } \\
\text { esastır. Toplumun gereksinimlerine göre iyileştirme } \\
\text { çalışmaları yapmak siyasi yapıların başat kaygısıdır. }\end{array}$ \\
\hline $\begin{array}{l}\text { Ekonomik alanda büyük bir eşitsizlik vardır. } \\
\text { Varolan dizge sermaye ve mülkiyete dayalıdır. }\end{array}$ & $\begin{array}{l}\text { Ekonomik eşitlik sağlanır. Sermaye ortadan kaldırılır ve } \\
\text { üretim araçları mülksüzleştirilir. }\end{array}$ \\
\hline $\begin{array}{l}\text { Toplumsal yapılar büyük bir çatışma halindedir. } \\
\text { İşçi ve köylü sınıfının yaşam ve çalışma koşulları } \\
\text { oldukça kötüdür. }\end{array}$ & $\begin{array}{l}\text { Toplumsal yapılar kaynaşır. Kent soylular asimile edilir. } \\
\text { Sınıfsız bir toplum oluşturulur. Halk refah içindedir. }\end{array}$ \\
\hline $\begin{array}{l}\text { Eğitsel alan dini kurumların etkisi altındadır ve } \\
\text { sadece zenginlerin çocukları bundan } \\
\text { faydalanabilir. }\end{array}$ & $\begin{array}{l}\text { Eğitsel alanda laik ve olgucu bir anlayış kabul edilir. } \\
\text { Herkes faydalanır. Kuram ve uygulama birleştirilir. } \\
\text { Etkin insan yaratılır. }\end{array}$ \\
\hline $\begin{array}{l}\text { Hukuk, kent soylu sınıfın emrindedir ve emniyet } \\
\text { güçleri halk tabakasına oldukça kötü muamele } \\
\text { eder. }\end{array}$ & $\begin{array}{l}\text { Sermaye ve mülkiyetin ortadan kalkmasıyla hukuk ve } \\
\text { emniyet güçlerine gerek duyulmaz. Hapishaneler } \\
\text { kapatılır. }\end{array}$ \\
\hline $\begin{array}{l}\text { Dini yapıların devlet kurumlarındaki etkisi } \\
\text { oldukça fazladır ve Katoliklik baskın dini } \\
\text { anlayıştır. }\end{array}$ & $\begin{array}{l}\text { Dini kurumlar ortadan yavaşça kalkar. Din insanların } \\
\text { hür vicdanına bırakılır. Esas olan olguculuk ve laikliktir. }\end{array}$ \\
\hline $\begin{array}{l}\text { Teknoloji işçiler için oldukça tehlikeli ve } \\
\text { kullanışsızdır. Fosil yakıtlar nedeniyle çevre } \\
\text { kirliliği oldukça artmıştır. }\end{array}$ & $\begin{array}{l}\text { Teknoloji insan için kullanışlı doğa için saygilı bir biçim } \\
\text { alır. Temiz yakıtların tüketilmesi ile çevre korunur. }\end{array}$ \\
\hline
\end{tabular}

\section{Açıklama aşaması: Aşkın Çözümleme}

İncelemekte olduğumuz yapıt üzerinde artsüremsel bir inceleme yaparak yapıtın ortaya çıktığ1 ve anlatının geçtiği çevreleyen yapıyla ne kadar ve nasıl bir ilişki içerisinde olduğunu ortaya koymaya çalışmak, yapitın metin boyutunu aşan aşkın çözümleme aşamasını oluşturur. Bu aşamada yapıtın oluşmasında 
doğrudan veya dolaylı etkileri olan dönemin ve toplumun tarihsel, toplumsal, siyasal, eğitimsel, vb. yapıların ele alınması ve yapıta yansıyan dünya görüşünün açıklanması gerekir.

\section{a. Tarihsel ve Toplumsal Olaylar}

Sanayi devrimine bağlı olarak artan meta üretimi anamalcı pazar anlayışını geliştirir ve kırsaldan kente yönelen göçlerde büyük bir artış olur. Buna bağlı olarak Fransız toplumu geleneksel tarım toplumu yapısından fabrika ve atölyelerde çalışan işçi ağırlıklı toplum yapısına doğru kayar. Uzmanlaşma, işbölümü ve artık değer sömürüsü hız kesmeden yaygınlaşır, bu da sınıf çatışmalarına neden olur. Erkin anamalcı dönem bütün XIX. yüzyılı kuşatır. Üretilen malın niteliğinden çok niceliği önem kazanır hale gelir. Bütün bunlara kentleşme, nüfus yoğunluğu, toplumsal yapılarda değişim, siyasi çalkantılar, ekonomik krizler ve değişimler eklenir. Eğitimin daha kaçınılmaz olmasından, ülkelerin askeri yapılanmalarına varıncaya kadar her şeyde bir değişim söz konusu olur.

Goldmann, Avrupa’nın anamalcllı tarihini inceler ve XIX. yüzyll boyunca süren dönemi erkin anamalcılık dönemi olarak adlandırır. Bu dönem boyunca bireycilik, akılcılık ve deneycilik gibi anlayışlar bütün kurumlara egemen olur. Bu dönemin son çeyreğinde oldukça önemli olaylar gerçekleşir, toplumsal yapılar ve kurumlar tümüyle dönüşüme uğrar. Ekonomik alanda serbest pazara dayalı bir anlayış süregelir, ancak devlet eliyle halka birçok alanda ayrıcalık ve olanaklar tanınır. Siyasal çoğunluk monarşistlerin elinde olsa da kraliyet aileleri arasında gruplaşmalar su yüzüne çıkar. Bu durumdan yararlanan cumhuriyetçiler siyasal alanda ülkenin yönetimini üstlenir (Maurois, 1947, s. 495). 1875 Şubatında III. Cumhuriyetin anayasası ilan edilir. III. Cumhuriyet yönetiminin uyguladığı olumlu politikalar uluslararası ve ulusal düzlemde güveni sağlar. 1881-82 yıllarında Jules Ferry'nin önderliğinde eğitim 6-13 yaş arasındaki çocuklar için zorunlu ve laik hale getirilir. İlkokullar ve kızlar için özel liseler açıllir (Duby, 1999, s. 747). Okullarda kuram ve uygulama birlikte yapılır. Belirli bilimsel alanlarda verilen derslerin yanında vatan sevgisi aşılanır. Kuzey Afrika ve Uzak Doğu Asya sömürgeleştirilir. 1880-90'lı yıllarında sömürgecilik çalışmaları hızını artırır. Sanayileşmeyle beraber toplumda yeni bir zengin sınıf ortaya çıar. Bu sınıf siyasi alanda yetkin, toplumsal alanda saygin ve ekonomik alanda oldukça etkindir. 1870-90 arası hafif sanayiden ağır sanayiye geçilir. Kömür en başlıca enerji kaynağı olur. Demir ve çelik üretimindeki yeni uygulayımlar sayesinde gemiler ve demir yolları daha hızlı üretilir hale gelir, ulaşım ve taşıma kolaylaşır (Bouguinat \& Pellistrandi, 2005, s. 108-130). Ülkenin dört bir yanına köprüler, tüneller, köprüyollar, barajlar ve demiryolları yapılır. Son olarak, Amerikan iç savaşından sonra Fourier'nin ütopik sosyalizmini benimseyen Amerikan hareket, belli bir etkinlik dönemi geçirir. Fransız göçmen Ernest de Boissière’in öncülügünde Kansas Silkville'de kurulan kolonide yeni ortaklık toplulukları oluşturmaya yönelik birkaç girişim olur (Sarcey, Bouchet, \& Picon, 2003, s. 96). 1840'lardan itibaren dünyanın birçok yerinde, özellikle Kuzey Amerika'da benzer girişimler gerçekleşir, ancak sermaye eksikliği, iş bilmezlik, dinsel ve ideolojik tartışmalar gibi nedenlerden bu girişimler üç yıldan fazla ayakta kalamaz.

XIX. yüzyılda Avrupa siyasetinin mimarları tüccarlar ve sanayiciler olur. Sahip oldukları ayrıcalıkların korunduğundan emin olmak için devletin bütün kurumlarına nüfuz ederler. Adam Smith bu kişileri insanoğlunun efendileri olarak adlandırır. "Yeryüzündeki bütün çağlar boyunca, insanoğlunun efendilerinin kem özdeyişinin, her şey kendimiz için diğer insanlara hiçbir şey yok doğrultusunda olduğu anlaşılmaktadır" (Smith, 1997, s. 336). Toplumun en önemli kaygısı çoğunluğa nazaran azınlığın imtiyazlarının korunmasıdır. Güç dengeleri yavaşça aristokrasiden bürokrasiye doğru kayar. Seküler kişiler ve Katolikler arasındaki anlaşmazlık cumhuriyetçiler için bir firsat olur ve yönetimi devralırlar. Toprağa dayalı zenginlik anlayışı yerini sermayeye bırakır. Kentsoylu sınıfa mensup ailelerin çocukları ilgi gören ve nitelikli eğitim veren büyük okullarda genellikle mühendislik, madencilik, askeri, iktisat, siyaset ve ilahiyat üzerine eğitim alır. Ekonomik alandaki en büyük çekişme muhafazakârlar ve serbest piyasacılar arasında gerçekleşir. III. Cumhuriyet dönemi boyunca genellikle yüksek, orta ve küçük kent soylulardan oluşan muhafazakâr anlayış benimsenir. Sömürgecilikle birlikte sanayicilik ve bankacıllk alanında da büyük atilimlar olur (Ponteil, 1968, s. 270).

III. Cumhuriyet ilan edilmesiyle işçilerin çalışma ve yaşam koşullarında belli oranda iyileşmeler gözlemlenir. 1873'e kadar emekçilerin büyük çoğunluğu tekstil, giyim, kozmetik ve gida sanayisinde çalısırr. Bu dönemden sonra ağırlık merkezi demir çelik ve maden sanayisine kayar. Çalışma saatleri 12 saat olarak belirlenmesine rağmen işçiler günlük 15 saate çalışmayı sürdürmek durumundadır. İşçi ücretleri oldukça yetersizdir, ancak aşırı üretime karşılık ekonomik bunalımın sürmesi ürün fiyatlarının düşmesine ve işçi ücretlerinin alım gücünün artmasına neden olur. Bir işçi ailesinin geçinebilmesi için ailenin tüm bireylerinin çalışması gerekir. Roman içeriğine yansıyan dönemlerde erişkin erkek işçiler günlük 2 frank, kadınlar 1 
frank, 9-12 yaş aralığındaki çocuklar 45 sent ve 13-17 yaş arasındaki gençler 75 sente çalışır (Villermé, 2006, s. 134). Alınan düşük ücretlere karşın işverenler daha az ücret ödemek için ücretler üzerinde oynamaya çalışır. Kırsal kesimden kente göçmüş işçiler genellikle tek odalı dairelerde yaşarlar. Yoğun işçi nüfusunun olduğu sanayi kentlerinde sıklıkla üç metrekarelik dairelerde beş veya altı kişinin yaşadığ da bir gerçeklik olarak kayıtlara yansır. Odalar nemli, penceresiz, havasız ve kışın çok soğuk, yazınsa çok sıcaktır (Dolléans, 2003, s. 18). Bütün bu kötü koşullara karşı 30 Haziran 1881 tarihinde işçilerin toplu eylem yapması anayasal hak olarak kabul görür. Sonrasında, 21 Mart 1884'te işçi sendikaları ekonomi, ticaret ve sanayi alanlarında söz sahibi olur. 29 Temmuz 1881 'de ise basın özgürleşir. Mutualizm ${ }^{5}$, kolektivizm ${ }^{6}$ ve anarşizm ${ }^{7}$ gibi ideolojiler güç kazanır. 1871'den 1890'a kadar toplamda 11.000 işçi grevi gerçekleşir. 1879 yllında Sosyalist İşçiler Partisi Federasyonu tarafindan düzenlenen kongreye Fransız sosyalizminin kurucusu sayılan Jules Guesde yanlısı birçok kişi katılır. İşçilerin toplumsal sorunları ve özgürleşmesi üzerine ciddi tartışmalar gerçekleşir. Guesde yanlısı Fransız İşçi Partisi yerel ve genel seçimlerde oldukça başarılı sonuçlar elde eder. Sosyalistler tarafindan kazanılan bölgelerde sosyal yardıma dayalı uygulamalar yapilır, işçi mücadelesi desteklenir ve hükümet sertçe eleştirilir. Yeni bir siyasi uygulama başlatılır (Noiriel, 1986, s. 105).

Köylü sınıfı diğer bütün toplumsal sınıflara göre daha perişan bir halde bulunur. Çaresiz durumdaki köylüler geçim sıkıntısı çeker ve çoğunluğu toprak sahiplerinin arazilerinde çalısan köle durumundadır. Toprak sahibinin onlar üzerinde büyük bir baskısı vardır ve onların emek gücüyle zenginleşirler. Toplumsal gelişmelerden habersiz, dünyaya kapalı bir kitleyi oluşturan işçiler, şehirlerdeki fabrika ve atölyelerdeki çalışma ve ücret koşullarının başkasının toprağında karın tokluğuna çalışmaktan daha iyi olacağı düşüncesiyle çareyi şehirlere göç etmekte bulurlar. Bir kısmı mevsimlik, bir kısmı sürekli işçi olarak çalışma yaşamı içinde yer alır. Aralarında ciddi bir birlik veya sendikalaşma yoktur. Bu nedenle özellikle daha küçük kentlerde daha fazla sömürülürler (Lhomme, 1970, s. 530).

Bütün bu toplumsal yapıların, eşitsizlik, adaletsizlik, ezilmişlik ve yozlaşma toplum bireyleri ve sınıfları üzerinde farklı biçimde bir bilincin oluşmasına neden olur. Böylesi bir durumda karşısında doğal olarak burjuva sınıfıyla işçi sınıfinın beklentileri farklı düzlemlerde oluşur. Kendini işçi sınıfi tarafinda konumlandıran yazar Emile Zola, bu sınıfin beklentileri, özlemleri ve sorunlarına çare bulunması konusunda aydın ve sözcü kimliğini öne çıkararak, işçi sınıfında oluşan bilinci daha sistematik hale getirerek şekillendirir. Döneminin bütün alt ve üst yapılarını mercek altına alıp, ortaya çıkan yeni siyasal öğretilerin var olan durumun yarattığı sorunlara çare olacağını düşünür ve kendince oluşturduğu model ve dünya görüşünü yapıtına taşır.

\section{b. Dünya Görüşü ve İdeoloji}

Yazarın büyük bir özenle oluşturduğu kişi kadrosu, Fransız toplumunda yer alan bilinç yapılarını yansıtacak çeşitlilik içerir. Lukács'a göre bilinç yansımaları yazınsal yapıtlarda kişiler aracıllğıyla gerçekleşir. Her bir kişi belirli bir bilinç yansımasını temsil eder ve doğrultuda hareket eder. Bu bağlamda yazarın kişi kadrosu yabancilaşmış, idealist, sorgulayan, sömürülmüş, sömüren, buyurgan, itaatkâr, tembel, çalışkan, yardımsever, bireyci ve genellikle birbirlerine zıt kişilerden oluşur. Yapıtta sahip olduğu toplumsal sınıfın değerlerini yadsıyan ve gerçek değerlerin, ilerici ülkülerin arayışında olan sorunsal kahramanlar olduğu gibi, içinde bulunduğu sınıfın bütün değerlerini özümseyen olumlu kahramanlar da vardır. Yazar, sözcülüğünü ya da temsilciliğini yaptığı toplumun karşı karşıya olduğu duruma model oluşturacak dünya görüşü veya ideolojisini romanın başkişisi aracilığıyla ortaya koyar.

Romanın başkişisi Luc aracillğıyla sözcülüğünü ve savunuculuğunu yaptığı öğretileri ve düşünceleri açığa vurur. Onları kutsar, ulular ve onlara güzellemeler yapar. Fourier ve Saint-Simon gibi ütopyacı toplumcuları yeni oluşturulacak düzenin bir anlamda peygamberleri olarak gösterir. Birçok toplumcu düşünür mevcut anamalcı dizgeyi ve gücü elinde bulunduran toplumsal sınıfı o dönemde en iyi şekilde eleştirdikleri için Fransa'nın gerçek aydınlanmacılarının bu isimler olduğunu savunur. Zola da aynı doğrultuda düşündügü için onların öğreti ve ideolojilerini benimser ve roman evreninde onları model aldığını açıkça belli eder. İnsanın insanı sömürmesini gerçekleştiren anamalcıllğın, üretim araçları ve özel

5 Çıkar elde etmeyi dışlayan, paylaşım ve dayanışma halinde karşılıklı güven ve anlayışı etik bir yaşam biçimi olarak öneren öğreti.

6 Yürütme ve karar mekanizmalarının toplumsal kesimlerin temsilcilerinin toplum adına ortaklaşa yürütülmesiyle oluşturulan toplumsal ve siyasal teşekkül.

7 Her türlü hiyerarşi ve otoriteyi dışlayan düşünsel ve siyasal akım. 
mülkiyetin toplumun veya kamunun malı olmasıyla aşılabileceği (Hançerlioğlu, 1977, s. 352) düşüncesi benimsenir.

Emek kavramı XIX. yüzyılın bütün toplumcu öğretilerine konu olur. Emek, insanın özünün bulunabileceği bir coşku kavramı olarak kabul edilir. Proudhon, "toplumun kurucu biriminin aile değil atölye olduğunu bildirir” (Sarcey, Bouchet, \& Picon, 2003, s. 73). Bununla birlikte insanın emekle olan ilişkisi çarpıcı bir biçimde dile getirilir. Özyönetimsel yapıya bürünecek atölyelerin karşılıklı yardımlaşmayla emeği özgürleştireceği düşüncesi ortaya çıkar. Saint-Simon sanayicilerin, zanaatkârların, işçilerin, sanatçıların ve mühendislerin bir araya gelmesiyle büyük bir sanayi yapılaşmasının ve bilimsel alanda yetkinleşme okulunun kurulmasını önerir. Ona göre, üretim araçları onları kullanmayı bile bilmeyen sahiplerinden alınıp yetkin kişilerin eline verilmelidir. "Her şey sanayi aracıllğıyla, her şey onun için" formülüyle özetlenen bir sistemin ve bir partinin "sanayileşmecilik" şeklindeki adlandırrlmasında buluşurlar” (s. 206). Aristokrasiyi, ruhban sinıfinı, askeri kesimi, bankaları, idari ve hukuki yapıları üreticilere musallat olmuş eşek arıları olarak tanımlar (s. 207).

Zola'nın romanda öğretisini model olarak sunduğu Charles Fourier, insanı oluşturan bütün tutkuların ve ahlaki olguların özgürleştirilmesi üzerinde yoğunlaşır. O, insanı kıyamete götüren bütün olumsuz davranışları ve tavırları yasaklar ve insanları ortaklaşmaya yönlendirir. Ona göre her birey kendi potansiyelinin bilincine varacak ve toplum tutkuların yoğunluğuyla oluşturulacaktır. Bu ilkelerle oluşturulacak olan phalanstère, çevresindeki bölgelere de yayılacak ve bütün dünyaya ulaşacaktır. Düşünürün oluşturmuş olduğu öğreti şu ilkelere dayanır: Aile tarzında büyük uluslararası insanların birliği, ürünü birlikte üretme ve eşit bir şekilde dağıtma, herkes için eşit bir eğitim modeli, miras hakkının ve özel mülkiyetin kaldırılması, hiçbir ayrıcalığa sahip olmayan ve her an değiştirilebilir yönetim organları, fiziksel ve zihinsel mükemmelleşme (Rubel, 1958, s. 493). Fourier, öğretisinde gelecekte olabilecek sanayiye dayalı çevre sorunlarını da öngörerek, sanayinin temiz yakıt kullanımına yönelmesini ve doğal kaynakların hakkaniyetli bir şekilde kullanılmasını öğ̈̈tler.

Tam anlamiyla bu ilkeler doğrultusunda olmasa da dünyanın birçok yerinde, Özellikle Kuzey Amerika'da, phalanstère'ler kurulur. Phalanstère’in amacı her türlü tutkuya sahip insanın her alanda ortaklık kurması ve yayılmasını sağlamaktır. Böylece eytişimsel bir hal alan Fourier’in öğretisi doğrultusunda oluşturulacak Phalanstère'ler içine kapalı değil, dişa açık bir toplum modeli olarak sunulur. Ancak oluşturulan ilk örnekler uzun ömürlü olmaz:

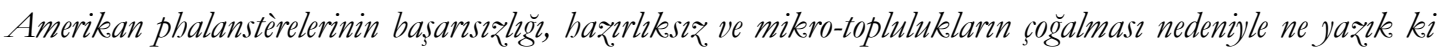 öngörülebilir türdendi. Gereken sermaye olmaksız!n kurulmus olduklar ve dini ya da başka tartısmalarn içine sürükelendikleri için topluluklarn çoğunun ömrü üc yul asmamıstır (Sarcey, Bouchet, \& Picon, 2003, s. 95).}

Dönemin sermaye sahiplerinin karşıtlıkları ve süregiden ekonomik-politik dizgenin yüzünden de bu komünler olumsuz etkilenir. Bunlara koşut olarak, aynı dönemde Proudhon ve Kropotkin gayretleri sayesinde anarşist komünizmin ortaya çıkması komünleri olumsuz etkiler. Bu anlayışa göre bireyler özgür ama aynı zamanda birlik; beldeler birbirinden bağımsız, ancak dayanışma içerisinde olmalıdırlar. Birbiriyle çelişir görünen öğretinin istekleri, zaten karışık olan aydın ve siyasetçilerin kafasının biraz daha karışmasına neden olur.

Zola tarafından okura yansıtılmak istenen dünya görüşü, birçok toplumcu, anarşist ve usçu düşünürün ögrretilerinden faydalanılarak oluşturulur. Bu kuramcılardan esinlenerek yeni bir dünya görüşü ve ütopya şekillendirir. Ütopyalar ve öncelemeler süregiden dönemi eleştirir ve geleceğe $1 s ̧ 1 \mathrm{k}$ tutar. Uzman bir gözle okuma sonrasinda bu romana, Francesco Nitti'nin Katolik Sosyalizm (Le Socialisme catholique), Kropotkin'in Anarşi, Felsefesi ve İdeali (L'anarchie, sa philosophie et son ideal), Charles Fourier'in Yeni Dünya (Nouveau Monde) adlı yapitlarıyla Saint-Simon, Comte, Proudhon ve Cabet'nin düşüncelerinin esin kaynağı olduğu açıkça görülür. Zola kaleme aldığ1 tüm yapıtlarında olabildiğince doğalcı kurama sadık kalır, onun çerçevesi ve ilkeleri doğrultusunda yapitlar verir. Ancak III. Cumhuriyet dönemiyle birlikte oluşturmaya başladığ1 Quatre Évangiles adlı roman serisinde insanın ve toplumun nasıl olması gerektiği konusunda kafa yorar, sağlıklı bir insan ve toplum yaratmaya yönelik düşüncelerini kaleme alır. Roman evrenindeki kişilerini oluştururken, Marksçıların yaptı̆̆ı gibi salt ekonomik olgulardan değil, biyolojik ve ekonomik olgulardan hareket eder.

Yukarıda adı geçen toplumbilimci ve düşünürlerin görüşleri doğrultusunda yapıta yansıyan dünya görüşünün tutarlıllğ1 ve özgünlüğünü sorgulamak gerekirse, şu saptamalar yapılabilir: Öncelikli olarak, oluşturulan dünya görüşü yazarın kendi bilincinde şekillendirdiği bir dünya görüşü değildir, yazar onu 
ancak farklı görüşlerin bir sentezini yaparak kendi tarzında biçimlendirmiştir. Buna ek olarak yazarın dünya görüşü var olan toplumsal koşullara ciddi boyutta eleştiriler getirse de, toplum düzenini sağlayacak somut bir dizge halinde uygulanabilir nitelikte değildir. Cü̈nkü büyük oranda etkilendiği Fourier'nin ütopyac1 toplumcu öğretisi de kendi içinde her ne kadar tutarlı ve mümkün görünse de, yaşama geçirilme noktasında öngörülmeyen engelleri aşmakta başarısız olur. Zola, toplumcu öğretilerin uzak bir gelecekte anamalcı ve kentsoylu yapının yıkılmasıyla, doğru tarihsel koşulları, bilinci ve yapıları oluşturarak ancak var olabileceğini ileri sürer. Marx bile, ütopyacı toplumcuların yaşadıkları dönemin tarihsel koşullarına oldukça uzak bir bakış açısına sahip olduklarını düşünür. Ona göre bu düşünürler işçi sınıfını siyasetten uzaklaştırmaya çalışıllar. Engels de bu düşünürleri sertçe eleştirmesine karşın toplumculuk, eytişsimsellik ve eleştiri konularında onları yüceltir. Engels'e göre (1974, s. 59), "Fourier yalnız bir eleştirici değil, serinkanlı ve duru yaradılışı onu bir yergici yapmışıి ve o, gelmiş geçmiş yergicilerin herhalde en büyüklerinden biridir. İdeolojilerle ilgili araştırmalarda sosyalizm, karşı tarafın ütopyasına karşı varoluşa yönelik bir yıkıcılıkla mücadele eden tutarlı bir eleştirel yöntem geliştirmektedir” (akt. Mannheim, 2002, s. 263).

\section{c. Bireyaşkın Özne ve Sorunsal Kahraman}

Birey olarak yazar, her zaman toplumun ve insanlığın aydını, düşünsel yönlendiricisi olarak kabul görür. Zira yazarın eylemi "yazmak", aynı zamanda derin düşünmek, gözlem ve çözümleme yapmak anlamlarına gelir. Roman bir yandan içinde yaşanılmakta olan toplumsal, siyasal ve tinsel durumların saptamasını yaparken bir yandan da olması gereken ideal toplum modelini sunan, çatışma, eksiklik ve aksaklıklara çözüm öneren kurgu evrenidir. Bu nedenle ulusların özellikle geçiş dönemlerindeki beklentileri, yazının daha çok düşünce içerikli olması ve insanlara 1şık tutması yönündedir. Buna koşut olarak, yazının amaç değil de araç olduğu dönemlerde sanat ikinci plana itilir ve herkes tarafindan kavranabilir ve anlaşılabilir nitelikli olan sav daha çok önem kazanır. Yazının toplumu öncelikli konuma getirmesi dönemin koşulları doğrultusundadır. XIX. yüzyıl yazar ve şairlerinin biraz da XVIII. yüzyıl aydınlanmacıları gibi birer düşünce adamlarıdır. Bu nedenle Zola'nın son romanlarını yazmasının asıl nedeni kurgusal yaşamın içine kendi savlarını yerleştirmek ve onların tanıtımını ve savunmasını yapmaktır. Emek adlı romanında Zola, toplumun ve insanlığın yeniden doğuş imgesini yaratır ve bu da yapıta destan niteliği kazandırır. Anlatıdaki bu derinlik yazarın, gözlem yeteneğinin, toplumsal sorunlarla çok yakından ilgilenmesinin göstergesidir (Tertemiz, 2018, s. 183).

Zor bir dönemden geçen Fransız toplumunu oldukça ayrıntılı inceleyen, hem yazar hem de eylemci kimliği olan Zola, son roman serisinde toplumda var olan sorunlara çözüm olabilecek öneriler ortaya koyar, imgesel bir dünyada bunların uygulamasını gerçekleştirir ve savunmasını yapar. Yapıttaki başkişi Luc, Zola’nın düşünsel anlamda sözcülüğ̈nü yapar. Luc, birçok usçu, ütopyac1, toplumcu ve anarşist düşünürün yapıtlarından etkilenmiş yazarın yarattığı ideal tip ve insandır. $O$, insanları yönlendirir, harekete geçirir ve güdüler. Zola ise XIX. yüzyılın sonlarına doğru, III. Cumhuriyetin ilanıyla, toplumcu düşünceyi benimseyen, sosyalist liderler ve çevrelerle sıkı ilişkiler kurarak 1880'li yıllardan itibaren çalıştı̆̆ gazetelerdeki köşe yazılarında, sosyalist, anarşist ve usçu düşüncenin savunuculuğunu yapan ve mevcut yönetim ile uygulamalarına oldukça sert eleştiriler getiren bir aydındır (Spiers \& Morgan, 1993, s. 39). O, yapitlarında sosyalizmin tek bir düşünürünün temsilciliğini yapmaz. Ütopyac1, anarşist ve usçu birçok düşünürün fikirlerinden yararlanır ve bunlardan bir sentez oluşturmaya çalıșır.

Emek'te bilim ve teknoloji konusu oldukça önemlidir. Bilim ve teknoloji insanları dogmalardan kurtararak özgürleştirecek ve refaha kavuşturacak tek araç olarak gösterilir. Luc, yeni dünya düzeninin kurulması ve gelişmesi için bu öğeleri vazgeçilmez olarak görür. Kamuya ait olması gereken üretim araçlarında özelleştirmeye yer yoktur, ancak insanların sahip olması zorunlu kişisel nesneler ve araçlar kendilerine aittir.

Bütün bunlar ışığında, romana XIX. yüzyıl Fransa'sındaki işçi sınıfının koşullarını taşıyan, eşitsizliklere ve ailelerin sefaletine yer veren ve toplum bilinci doğrultusunda çözüm önerileri sunan gerçek anlamdaki bireyaşkeın özne, Zola’nın kendisinden başkası değildir. Ancak görünürde romanın başkişisi bu rolü üstlenir. Emile Zola, sahip olduğu sosyalist dünya görüşü ve işçi sorunlarına olan ilgisi onu aydın, ifade yeteneği güçlü kimliğiyle zorunlu olarak bu statüye yerleştirir. Bu nedenle Zola, işçi sınıfının yaşam ve çalışma koşullarıyla ilgili çok ciddi araştırmalar ve gözlemler yaparak düşüncelerini yazılarına ve yapıtlarına aktarır. Birçok iş̧̧i eylemine katılır, birçok fabrika ve madeni gezer, hatta buralarda çalışma koşullarını deneyimler. Örneğin yazar, Germinal romanını yazmadan önce işçi kıyafetlerini giyip bir madende çalışır. Toprak adlı romanı için Beauce Bölgesini ziyaret eder ve detaylı incelemeler yapar. Loire'da mevcut bulunan işçi 
sendikalarıyla iletişim halindedir ve 1884 yllinda Anzin madencilerinin 56 gün süren grevine katıllir. Bu grevle ilgili yazılan birçok makaleyi öven ve yeren yazılar kaleme alır. Bunun yanı sıra Emek adlı yapitını daha da ayrıntılı kılmak için anlatının geçeceği uzamla ilgili araştırmalara başlar ve Bayan Ménard-Dorian'la iletişime geçer, Unieux'deki demir-çelik fabrikalarını görme izni alarak üç gün boyunca Zola burada kalır ve inceleme yapar (Mitterand, 1974, s. 201). Ayrica Zola, bu yapitı yazarken E. Bellamy'nin Jean Grave ve Kropotkin'den esinlenerek oluşturduğu Cent ans après ou l'an 2000 adlı yapıtının giriş bölümünü okuyup inceler (Tertemiz, 2018, s. 120-126). Bu dönemde bilim-kurgu ve öncelemeci romanların (fr. roman d'anticipation) sayısı oldukça artar ve Zola da bu romanıyla toplumsal bir önceleme roman örneği vermiştir denebilir.

Goldmann'ın çözümleye yöntemi, günümüz roman kişilerinin sorunlu/sorunsal kişiler olduklarına vurgu yapar. Çünkü ait olduğu toplumun, toplumsal yapılar ve dizgelerin çatışmasıyla mutsuzluğa sürüklendiğinin bilincine vararak, toplumuna ve toplum bireylerine mutluluğu ve eşitliği getirecek arayışlar içine girer. Emek'te sorunsal kahraman olan Luc, ortaya koyduğu çözüm modellerinin insanlar arasındaki eşitsizliği gidereceğine ve toplum bireylerinin mutlu olacağına inanır, bu doğrultuda tasarılarının yaşama geçirilmesinde etkin rol oynar, ancak çabası boşunadır. Romanın son bölümünde neredeyse tüm dünyayı kollarıyla saran anamalcı dizgenin çarkları arasından sıyrılmanın pek de olası olmadığının ayrımına vararak hayal kırıklı̆ıına uğrar. Gerçek değerlerin arayışında olan, ancak onlara erişmesi olası olmayan sorunsal kahraman Luc'e kendi aydın kişiliğini kazandıran Zola da toplumun başat sorunlarının ancak var olan düzenin tamamen değişmesiyle atlatılabileceğini savunur ve bu düşüncenin sözcülüğünü yapar. Bu sayede salt siyasi kanatta kalmamaya özen gösterir, hiçbir siyasi partiye üye olmadan hür iradesiyle hareket etmeye çalışır ${ }^{8}$. Yapıtında dönemin sosyalist görüşlerinin tarihsel bir panoramasını yapmaya çalışır ve her türden sosyalist görüşe oluşturmuş olduğu bu anlatıda yer vermeye özen gösterir (Dotoli, 2013). Ne var ki, sorunsal kahramanı gibi gayret ve çabaları düş ve beklentilerinin gerçekleşmesi noktasında sonuçsuz kalır.

\section{Sonuç}

Goldmann'ın Marksçı yazınsal inceleme yönteminden yararlanarak, eşsüremsel ve artsüremsel düzeylerde gerçekleştirilen çözümleme sonuncunda yazarın şekillendirdiği kurgusal evrendeki döneminin toplumsal olay ve yapılarından, ülkülerinden oldukça etkilendiği anlaşıllr. Yapıtı oluşturan içkin unsurlarla onu çevreleyen aşkın unsurların birbirleriyle tutarlıık gösterdiği saptanır. Yapıtın ilk yarısında ortaya konan toplumsal görüntünün oldukça gerçekçi ve eleştirel olduğu, buna karşıllk yazar tarafindan öznel veya nesnel bir biçimde yansıtılan manzaraların genelde yergisel ve kötücül olduğu fark edilir. Okura aksettirilen toplumsal çehre ve bireyler oldukça mutsuz ve esenliksizdir. Sermaye ve mülkiyete dayalı vahşi anamalcı dizgeden Fourier ve Saint-Simon gibi ütopyacı toplumcu öncülerin öğretileri 1şığında kurtulmanın mümkün olacağı ileri sürülür. Halka sunulacak olan değişim önerilerinde ekin konusu başat unsurlardandır. Dolayısıyla yazarın Fransız toplumcu düşünürlerini tercih etmesinin sebeplerinden birinin bu olduğunu söylenebilir ve yapıtın ilerleyen bölümlerinde anlatının önsüremsel zamana yerleşmesi de ütopyacılıktan faydalanma nedenini açılar. Yapıtın ikinci yarısından itibaren emekçiler dayanışma, yardımlaşma ve özgürlük gibi ilkelerin çatısı altında birleşmeye gayret ederler ve bu birleşme aydın nitelikli bir başkahraman aracıllğıyla gerçekleşir. Ancak emekçi sınıfın karşısında ona engel olmak için bütün gücünü ve olanaklarını kullanacak bir kentsoylu sınıfın varllğına dikkat çekilir. Benzer sorunları yaşayan veya yaşayacak toplumlara, Marx'ın da öne sürdüğü gibi, tarihsel eytişimin bu mücadelenin sonucunda haklı çıkacağı ve bilinmeyen bir gelecekte ezilen sınıfların gücü devralacağı düşüncesi ümit olarak sunulur.

Zola, Fransa'nın III. Cumhuriyet döneminde vuku bulan anamalcılık ya da toplumculuk tartışmasında toplumcu düşünceden yana tavır alır. $\mathrm{O}$, hayatı ve kariyeri boyunca işçi sınıfını yakından gözlemler ve yaşadıkları 1stıraplara birebir tanık olur. Bundan dolayı, yazarın bu yapıtında döneminin toplumcu düşüncelerinin bir panoramasını yapmaya gayret göstermesi şaşırtıcı değildir. Kaleme almış olduğu bu romanı dönemin toplumcu öğretileri için yapılmış bir tür tanıtım ve uygulama kitabıdır. Germinal romanındaki hararetli sınıf çatışmasına dayalı dünya görüşüne karşılık, Emek adlı çalışmasında toplumsal uzlaşıyı savunur. Ancak yazar, bunun tam anlamıyla olanaklı olmadığının farkındadır. Bundan dolayı yeni toplumcu düzene karşı olanlar ister istemez benzeştirilir yani yeni düzene uyum sağlamak zorunda kalırlar.

Zola, yaşamını yitirmeden önce tam olarak yazıp bitirebildiği bu son romanında doğalcı yazın uygulayımlarına mümkün olduğunca bağlı kalır. Özellikle yapıtın ilk yarısı tam anlamıyla doğalcı niteliklerle bezenmiş bir anlatıdır. Fakat yapıtın ikinci yarısından itibaren anlatı, önsüremsel bir uzama yerleşir ve

${ }^{8}$ Bknz: https://gallica.bnf.fr/ark:/12148/cb328051026/date1887 
toplumsal bir önceleme yapılır. Her ne kadar bu, doğalc1 kurama aykırı gibi görünse de, düşünür bu öncelemeyi döneminde gerçekleşen siyasal, toplumsal, eğitsel ve teknolojik ilerlemeleri temel alarak oluşturur. Oluşturulan toplumsal yapı ve düzen ise yazarın kendi dünya görüşünün bir ürünüdür. Fourier tarzı ütopik sosyalist öğreti kendi içerisinde oldukça tutarlı ve bütüncüldür. Bunun aracıllğıyla yazarımızın kendi ideal insanını ve toplumunu bu yapıttan yararlanarak oluşturduğu açıktır. 1840'lı yıllardan sonra dünyanın birçok yerinde Fourier'nin önerdiği phalanstère'lere benzer komün girişimleri olur. Saint-Simon ve Fourier görüşlerini benimseyen misyonerler onların öğretilerini yaymak için dünyanın dört bir yanında görev yapar. Yazarın da yaşama geçirilmesine tanık olduğu Paris Komünü gibi olaylardan sonra ülkedeki birçok muhalif görüşlü aydın Kuzey Amerika’ya sürgün edilir. Buraya giden aydınlar kıtanın birçok yerinde phalanstère ya da kooperatif kurma girişiminde bulunurlar. Ancak gerek sermaye eksikliği, gerekse içine düşmüş oldukları çeşitli tartışmalardan dolayı bu girişimler uzun süre varlıklarını sürdüremezler. Var olan anamalc1 ekonomik dizge bu komünlerin varlığını sürdürmelerine de olanak tanımaz.

\section{Etik Beyan}

“Oluşumsal Yapısalcılığın İlkeleri ve Zola’nın Emek Adlı Romanı Üzerinde Çözümleme” başlıklı çalısmanın yazım sürecinde bilimsel, etik ve alıntı kurallarına uyulduğunu; toplanan veriler üzerinde herhangi bir tahrifat yapılmamıs olduğunu ve bu çalışmanın herhangi başka bir akademik yayın ortamına değerlendirme için gönderilmediğini taahhüt ederiz.

\section{Kaynakça}

Atalay, İ. (2007). Jean-Paul Sartre'ın Özgürlük Yolları adlı yapıtına oluşumsal yapısalcı bir yakılaşım (Doktora Tezi). Atatürk Üniversitesi Sosyal Bilimler Enstitüsü, Erzurum.

Atalay, İ. (2016). Yapıt çözümlemesinde toplumeleştiri, yazın toplumbilimi yöntemleri ve Lucien Goldmann'ın oluşumsal yapisalcıllı̆̆. Humanitas 4(8), 387-412.

Atalay, İ; Er, A. (2013). Oluşumsal yapısalcılık bağlamında sorunsal kahraman ve dünya görüşü kavramları: Bernard Marie Koltès'in Batı Rıbtımı (Quai Ouest), Humanitas, 1(2), 27-42.

Baysan, G. T. (2010). Réflexions sur Travail de Zola: I. L'Abîme et les abîmes. Revue d'études et recherches sur les littératures du monde, s. 39-51.

Baysan, G. T. (2012). Reflexions sur Travail de Zola II. La Crecherie - vers la naissance de l'espoir. Revue d'études et recherches sur les littératures du monde, s. 41-48.

Bouguinat, N. ve Pellistrandi, B. (2005). Le 19e siècle en Europe. Paris: Armand Colin.

Dolléans, É. (2003, Juillet 9). Histoire du mouvement ouvrier Tome I : 1830-1871. (J.-C. Bonnier, Dü.) Chicoutimi, Québec, Canada.

Dotoli, G. (2013, Avril 14). Salon Littéraire. Juillet 18, 2018 tarihinde Linternaute: http://salonlitteraire.linternaute.com/fr/biographie-auteur/content/1830361-emile-zola-biographie adresinden alınd1

Dönmezer, S. (1994). Toplumbilim (11. Baskı). İstanbul: Beta Basım Yayım Dağıtım A.Ş.

Duby, G. (1999). Histoire de la Frace des origines à nos jours. Montréal: Larousse.

Engels, F. (1974). Ütopik sosyaliz̧m ve bilimsel sosyaliz̧m (Çev: Ö. Ünalan). Ankara: Sol Yayınları.

Escarpit, R. (1993). Edebiyat sosyolojisi (Çev: A. Yazıc1). İstanbul: Remzi Kitabevi.

Girard, R. (2013). Romantik yalan ve romansal hakikat (Çev: A. İldem). İstanbul: Metis Eleştiri.

Goldmann, L. (1950, Juillet-Septembre). Matérialisme Dialectique Et Histoire de la Littérature. Revue de Métaphysique et de Morale, s. 283-301.

Goldmann, L. (1962, Janvier-Juin). Problèmes d'une Sociologie du Roman. Cabiers Internationaux de Sociologie, s. 61-72.

Goldmann, L. (1964, Mai). Le Structuralisme Génétique En Histoire De La Littérature. MLN, s. 225-239.

Goldmann, L. (1964). Pour Une Sociologie du Roman. Paris: Gallimard.

Goldmann, L. (1976). Diyalektike Araştırmalar (Çev: A. Timuçin ve M. Sert) İstanbul: Kavram Yayınları.

Goldmann, L. (1976). Le Dieu Caché. Paris: Gallimard.

Goldmann, L. (1977). Insan bilimleri ve felsefe (Çev: A. Timuçin ve F. Aynuksa) İstanbul: Kavram Yayınları.

Hançerlioğlu, O. (1977). Düsünce taribi İstanbul: Remzi Kitabevi.

Herschberg Pierrot, A. (2003). Stylistique de la Prose. Paris: Belin.

Kocka, J., \& Mitchell, A. (2015). 19. Ÿ̈̈zyl Avrupa'sında burjuva toplumu (Çev: U. Kocabaşoğlu) İstanbul: İletişim.

Krapivin, V. (1988). Diyalektik materyalizm nedir? İstanbul: Bilsan A.Ş. Bilim ve Sanat.

Lhomme, J. (1970). La crise agricole à la fin du XIXe siècle en France. Essai d'interprétation économique et sociale. Revue économique, XXI, ss. 521-553.

Lukács, G. (1987). Avrupa gerçekçiliği (Çev: M. H. Doğan) İstanbul: Payel.

Mannheim, K. (2002). İdeoloji ve ütopya (Çev: M. Akyayuz) Ankara: Epos Yayınları.

Maurois, A. (1947). Histoire de la France Paris: Editions Dominique Wapler.

Mitterand, H. (1974). Enquête sur une visite de Zola à Unieux pour la préparation de «Travail ». J. Naumont içinde, Les Cabier Naturalistes (s. 182-204). Paris: Éditions Fasquelle. 
Munier, B. (2001). De la Sociologie du Roman au Roman Sociologique. L'Année sociologique, s. 185-203.

Noiriel, G. (1986). Les ouvriers dans la a société française XIX-XXe siècle. Paris: Éditions du Seuil.

Özdemir, E. (1999). Yazınsal türler. Ankara: Bilgi Yayınevi.

Özdemir, E. (2000). Eleștirel okuma. Ankara: Bilgi Yayınevi.

Ponteil, F. (1968). Les Classes Bourgeoises et l'avènement de la Démocratie. Paris: Éditions Albin Michel.

Raimond, M. (2008). Le Roman. Paris: Armand Colin.

Rubel, M. (1958). De l'utopie à l'idéologie. Revue d'bistoire économique et sociale, s. 491-496.

Sarcey, M. R. D., Bouchet, T. D. ve Picon, A. (2003). Ütopyalar sözlüğ̈ (Çev: T. Ilgaz) İstanbul: Sel Yayıncilık.

Schmitt, M. ve Viala, A. (1982). Savoir-Lire. Paris: Didier.

Smith, A. (1997). Uluslarn z̧enginliği (Çev: M. B. Ayşe Yunus) İstanbul: Alan yayıncılık.

Spiers, D. E. ve Morgan, O. (1993). Les linéaments d'un Évangile: les interviews de Zola à l'époque des Trois Villes. A. Pagès içinde, Les Cabiers naturalistes (s. 35-46). Paris: Grasset-Fasquelle.

Tertemiz, S. (2018). Une étude sur Travail d'Émile Zola dans le cadre de la méthode de structuralisme génétique (Yüksek Lisans Tezi). Namık Kemal Üniversitesi Sosyal Bilimler Enstitüsü, Tekirdağ.

Tilbe, A. (1999). Albert Camus'un Veba adlı Romanına Toplumbilimsel bir Uygulama. Edebiyat ve Toplum Semposyumu Bildirileri (s. 105-111). Gaziantep: Ankara Üniversitesi Tömer Yayınları.

Tilbe, A. (2000). Une Etude Sociologique Dans la Peste d'Albert Camus. Erzurum: Université Ataturk Institut des Sciences Sociales.

Tilbe, A. (2004). Sartre’ın Bekleyiş Adlı Romanına Goldmann'cı Bir Yazın Toplumbilimsel Yaklaşım. K. Alver içinde, Edebiyat Sosyolojisi Incelemeleri (s. 92-116). Ankara: Hece Yayınları.

Tilbe, A. (2010, Haziran). George Lukacs ve Lucien Goldmann'ın yaklaşımıyla fransız yazınında kişi sorunsalı. Batı Edebiyatında Kahraman, 17, 27-36.

Tilbe, A. ve Tekin, P. (2013). Andre Malraux'un Insanlık Durumu: Oluşumsal Yapısalcı Bir Okuma. 8. Ulusal Frankofoni Bildirileri Kitabr, (s. 242-254). Tekirdağ.

Tilbe, A. ve Tilbe, F. (2015). Reşat Enis Aygen'in Afrodit Buburdanında Bir Kadın adlı romanında çalışma ilişkileri: yazın toplumbilimsel oluşumsal yapısalcı bir inceleme. Humanitas, 5, 187-216.

Tilbe, A. ve Tilbe, F. (2016). Yazın toplumbilimsel oluşumsal yapısalcı bir çözümleme: Mahmut Yesari'nin çulluk adlı romanında çalışma ilişkileri. Uluslararası Edebiyat veToplum Sempozyumu Bildiriler Kitabı (s. 123-134). Bartın: Bartın Üniversitesi Edebiyat Fakültesi Yayını.

Veron, L. ve Fondu, Q. (2015). Lucien Goldmann (1913-1970) : Pour un marxisme humaniste. Intervention dans le cadre du séminaire Lectures de Marx. https://f.hypotheses.org/wp-content/blogs.dir/851/files/2015/11/LucienGoldmann-1913-1970-Pour-un-marxisme-humaniste-Lae\%CC\%81lia-Ve\%CC\%81 ron-Quentin-Fondu.pdf, 12.03.2019.

Villermé, L. R. (2006, Mars 9). Tableau de l'état physique et moral des ouvriers employés dans les manufactures de coton, de laine et de soie. Chicoutimi, Québec, Canada.

Yücel, T. (1982). Yapısalcullk. İstanbul: Ada Yayinları.

Zola, É. (1881). Le roman expérimental (5e édition). Bibliothèque nationale de France.

Zola, É. (2010). Emek (Cilt II). İzmir: İlya Yayınları.

Zola, É. (2010). Emek (Cilt I). İzmir: İlya yayınları.

\section{EXTENDED ABSTRACT}

After the widespread reading of literary genres and products, the intellectual people began to question what they read and to examine the structure of the content and style. In this way, different methods of criticism were born with the development of evaluation methods and perspectives of the individuals who took the role of critics because they could not reach a consensus on the relative evaluations which have become a scientific branch developing over time. One of these methods of criticism, which takes different criteria as a point of action, is the Marxist way of thinking, which has deeply influenced the economic and political life of the post-nineteenth century and has shaped political regimes, and the sociology of literature, which is fed from this way of thinking.

Although literature is an area where different critics of different dimensions have been inclined for centuries and even though they have lived in western European space, the Marxist worldview has been developed by György Lukács, Lucien Goldmann and many other theorists, and it is divided into subbranches with different names. One of the sub-branches of Goldmann's method of criticism is shaped by the name of genetic structuralism. In order to cover also different aspects of the process which are from the formation phase of the literary work in the mind to the consumption phase, this method of genetic structuralism is called in this name. This means that the method has a structuralist and formative dimension.

Genetic structuralism, qualified and content of social, economic, political, educational, cultural, etc., offers two stages in the analysis of literary works that address the conflict between structures and strings: 
the understanding phase and the explanation phase. The understanding phase forms the stage of examining the text size of the work. The narrator, which includes narrative techniques on the basis of narrative, requires the focus of the narrator, type of narrative, narrative people, narrative and narrative time, space and other structures reflected in narrative. On the other hand, it is investigated how the author, who is the representative and spokesperson of the intellectual individual, who is conscious of the society or the social class, shapes and transfers the social consciousness on behalf of the social group he belongs to according to the method of criticism. In this context, awareness of conflicts and problems in society, conflict and solutions to problems that affect the process of proposing alternative structures or strings that contain a wide range of social sub and upper structures.

In order to meet the expectations of society, the author's worldview or ideology in the novel universe is usually the author's own intellectual ability. The hero of the novel, who seeks to ensure the welfare and happiness of the society he lives in, has no chance of succeeding against the world dominated by the capital economic system. The hero, constantly pursues true values and strives for the happiness of himself and of society, cannot go beyond being a problematic hero because he no longer has the chance to achieve his goal in a world without real values. In this case, the solution is to destroy the capital string, instead of activating a new string that enables a sharing life in which people communicate with each other. In the near future, such a thing is unlikely, so the search for the novel hero continues to go in vain. Emile Zola, within the framework of the theory of naturalism adopted in the second half of the nineteenth century, reflects the real events and situations experienced in society through research, observation and experimentation with the diligence of a scientist to the novel universe. Observed that the problems of the Working Class, a new social class formed in the country by the development and spread of industrialization at the time, were increasing, and the strategies of the bourgeois who formed the employers section were followed by paying less in return for the labour, Zola also adopts the socialist teachings defending social justice and equality, bringing the consciousness created by the society to the masses through his novels, which he wrote as a representative.

Novels, included the narratives of individuals seeking solutions to problems in order to achieve happiness, are a very suitable field of study for Marxist doctrine which adopts the understanding of social realism and the methods of criticism that have passed from this doctrine. The method of genetic structuralism of Goldmann, which forms one of the methods of Marxist-based social critique, is also recommended as the method of solving or criticizing the problems caused by the capitalist string and the problems of the novel, which describes the proposed solutions to them.

In addition to the interior structures of the work, the method that proposes research on non-text structures that affect and trigger the process of formation of the work, queries the world view or teaching of the writer who is the representative of the society in the face of problems. In the implementation phase of the method, in-depth research of different structures creates consistent and logical explanations. Accordingly, the method of genetic structuralism gives successful results in applying it to novels containing traces of social conflict, search for new order, contrasts, and oppression.

Zola's Novel, in which utopian socialism is defended, is based on the basic thesis that, due to the liberalization of labour, all sentiments and pleasures in life will become meaningful and that humanity will be happy in this way. The work who shows how the bourgeois class, developed as a parallel to the industry, enslaved people in the nineteenth century, convey in model narratives that liberation from labour slavery would give humanity the opportunity to create a new world order. While the work indicates that the heavy conditions of the working class can be overcome by rational and rational solutions, it presents in natural ways Zola's ideas inspired by utopian socialist Charles Fourier, Saint-Simon and many other social socialist thinkers and writers. 